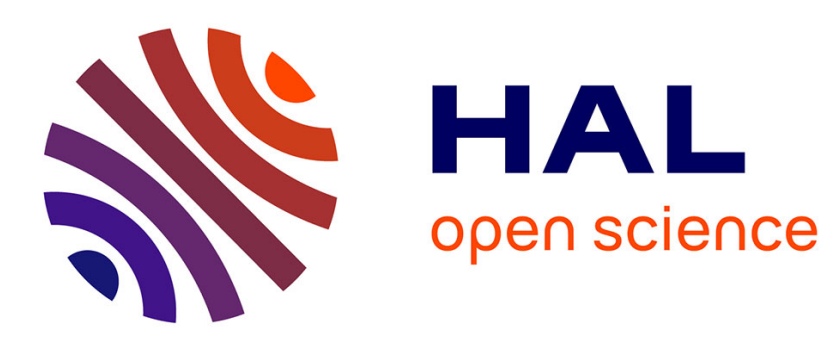

\title{
Case Selection and Judicial Decision-Making: Evidence from French Labor Courts
}

\author{
Claudine Desrieux, Romain Espinosa
}

\section{To cite this version:}

Claudine Desrieux, Romain Espinosa. Case Selection and Judicial Decision-Making: Evidence from French Labor Courts. European Journal of Law and Economics, 2019, 47 (1), pp.57-58. 10.1007/s10657-018-9594-7 . halshs-01827472

\section{HAL Id: halshs-01827472 \\ https://shs.hal.science/halshs-01827472}

Submitted on 2 Jul 2018

HAL is a multi-disciplinary open access archive for the deposit and dissemination of scientific research documents, whether they are published or not. The documents may come from teaching and research institutions in France or abroad, or from public or private research centers.
L'archive ouverte pluridisciplinaire HAL, est destinée au dépôt et à la diffusion de documents scientifiques de niveau recherche, publiés ou non, émanant des établissements d'enseignement et de recherche français ou étrangers, des laboratoires publics ou privés. 


\title{
Case Selection and Judicial Decision-Making: Evidence from French Labor Courts
}

\author{
Claudine Desrieux* and Romain Espinosa ${ }^{\dagger}$
}

June 2018

\begin{abstract}
Using a database on French labor courts between 1998 and 2012, we investigate case selection and judicial decision-making. In France, judges are elected at the labor court level on lists proposed by unions, and litigants can first try to settle their case before the judicial hearing. We show that the ideological composition of the court indirectly impacts the settlement behavior of the parties but has no influence on the decision made in court. In addition, parties have self-fulfilling behavior and adapt to institutional rules. When they anticipate long judicial procedures at court, they settle more frequently and only require judicial hearings for complex cases. The duration to decide these complex cases is longer, explaining why they observe (and build their anticipation on) long case duration. Our empirical strategy uses probit, ordered probit and triprobit estimations to control for case selection.
\end{abstract}

JEL codes: K31, K41

Keywords: Settlement, case duration, judicial proceedings, labor courts, unions.

\section{Introduction}

Under perfect information, litigation models suggest that parties anticipate the judicial decision, and then prefer to settle rather than to go to trial (Cooter and Ulen (2016)). Yet, observed behaviors show that parties often fail to settle and decide to go to court. As suggested by the behavioral literature (e.g., Loewenstein and Babcock (1993)), this may be caused by limited cognition and psychological biases distorting the perception of the parties' chances to win. On the other side, studies on judicial decision-making also suggest that judges' decisions may be partially driven by their ideological preferences. Uncertainty about the impact of ideological preferences on the judges' decisions makes outcomes harder to anticipate for the parties. In this paper, we empirically analyze the decision of the parties to settle or to litigate in courts with judges known to have different ideological positions, but whose effects on judicial outcomes are not clearly defined.

French labor courts provide an excellent framework to study both judicial decisions and settlement strategies. First, judges are elected at the local level, on a parity basis between representatives of employers and employees. Lists of candidates are established by unions, so that the elected judges belong to different unions, known to be more or less harsh regarding workers' protection. Courts

${ }^{*}$ CRED - Université Paris II. Email : claudine.desrieux@u-paris2.fr

${ }^{\dagger}$ CNRS, CREM - Université Rennes 1. Email : romain.espinosa@univ-rennes1.fr 
then differ according to their composition, i.e. their level of ideological polarization, which provides great sources of spatial and temporal variations. Second, the institutional setting requires decisions to be made at the majority of an even number of judges. Polarization can then increase the probability of a tie, resulting in additional hearings. Polarized courts are therefore expected to increase delays of procedures and to increase the litigation costs. Third, French litigants have the possibility to settle their cases in-court at the beginning of the procedure. Alternatively, they can settle outside the court, as long as the judges haven't decided on the case.

Our goal is to understand whether the ideological composition of courts influences the decision made by judges (including cases of tie), and by anticipation, the strategy of the parties to settle. To do so, we rely on data on French labor courts that comprise all cases opened between 1998 and 2012. These data allow us to determine, for each case, litigants' settlement decisions and the judicial outcome. We match each observation with the composition of the court at the time the case was settled. It allows us to capture litigants' anticipations of the ideological composition of the court, and the associated impact on litigants' and judges' decisions. Our empirical investigation relies on probit estimations, with controls for potential endogeneity. We also use triprobit estimations to correct for the selection effects due to strategic settlement.

Our results show strong evidence supporting the fact that litigants adapt their settlement strategy to the type of court they face. When courts are ideologically polarized, which is likely to increase delays to reach a decision, litigants settle more often both in court and out of court. This strategic settlement implies that judges in polarized courts face more complex cases. By anticipating longer delays, parties settle the easiest conflicts, leaving judges with the most difficult cases. Controlling for case selection, we show that judges with different affiliations do not differ in their decision. In other words, the litigants' very own behaviors drive the longer delays they seek to avoid: only the most complex cases are left for litigation, explaining the longer delay to reach a final decision.

Our paper contributes to the literature on case selection and judicial decision-making. Our originality is to embrace both theoretical frameworks into a single empirical investigation. In addition, our study relies on European data while most of the previous literature has explored American data.

The remainder of the paper is organized as follows. Section 2 relates our paper to the previous economic literature. Section 3 describes the institutional framework of French labor courts. Section 4 presents our data. An empirical analysis is presented in section 5. Complementary investigations are led in section 6. Discussion and concluding remarks follow in section 7.

\section{Literature review}

Our paper is related to two strands of the law and economics literature, namely (i) the literature exploring the decision to settle or to litigate, and (ii) the literature on judicial decision-making.

Following Priest and Klein (1984), many papers have searched for empirical evidence on the selection of cases sent to trial. ${ }^{1}$ Some papers support the proposition whereby the plaintiff win rate is close to $50 \%$ in courts: cases sent to court (instead of being settled) are mixed-evidence cases (Waldfogel (1995), Kessler et al. (1996), Klerman (2012)). But these empirical results have been challenged in other contributions showing that more clear-cut cases can be brought to court (Eisenberg (1991), Eisenberg (1994), Clermont and Eisenberg (2002)). In addition, other determinants of settlement have been investigated. Settlement rates can vary according to the field of law (Gross and Syveryd (1991); Eisenberg and Lanvers (2009)), the values of the claims (Lederman (1999)), legal representation (Huang (2008)) or the characteristics of the judges (Berlemann and Christman

\footnotetext{
${ }^{1}$ We focus here on the empirical literature. However, case selection has also led to a large theoretical literature. Surveys for this theoretical literature are provided by Hay and Spier (1998) and Daughety and Reinganum (2012).
} 
(2016)). Eisenberg and Farber (1997) show that lawsuits where the plaintiff is an individual have higher trial rates than those where the plaintiff is a corporation. More broadly, they suggest that trial rates are more affected by the identity of the plaintiff than by the identity of the defendant. More related to labor courts, Huang et al. (2010) use Taiwanese data, and find that increasing stakes decreases the probability of settlement, decreases the percentage of the claim recovered in settlement, and increases the probability of litigation after settlement fails. They also show that the mediation mechanism allows workers with small claims to obtain effective recovery, which would be impossible if those workers had to resort to litigation. Last, using Mexican data, Kaplan et al. (2008) find that workers receive higher percentages of their claims in settlements than in trial judgments. They also show that cases with multiple claimants against a single firm are less likely to be settled, which partially explains why workers involved in these procedures receive lower percentages of their claims. Finally, they find evidence that a worker who exaggerates his or her claim is less likely to settle. Our paper is related to this literature as we investigate the settlement decision. Our focus is on the impact of the ideological composition of the courts.

Regarding the literature on judicial decision-making, early works have focused on Supreme Courts. They provide evidence that political preferences of Justices impact judicial votes (Segal and Spaeth (1993, 1996); Hitt (2013)), even if they are not the unique determinant (Perry (1994); Epstein and Kobylka (1994); Espinosa (2017)). ${ }^{2}$ Further works have shown that other personal characteristics may also matter. Gender or family situations appear as significant determinants of judicial decisions in some settings (Kulik et al. (2003); Peresie (2005); Boyd et al. (2010); Glynn and Sen (2015)), as well as racial bias (Farhang and Wawro (2004); Shayo and Zussman (2011); Anwar et al. (2012)). The political, economic and social environment can also have a significant impact on the decisions made by judges. For instance, investigating labor courts, Ichino et al. (2003) and Marinescu (2011) have shown that macroeconomic conditions impact acceptance or rejection decisions. Beyond the personal characteristics of the judges, institutional arrangements, i.e. how courts are structured including recruitment and retention processes, also matter. The selection of judges (nomination or election) has been found meaningful regarding judicial decisions (Lim (2013)). Elected judges seem to balance policy goals against re-election or career needs (Hall (1987, 1992); Brace and Hall (1995)). Both ideology and institutional features can combine their effects. With U.S. data, Brace et al. (2012) show that state supreme courts having discretionary dockets allow judges greater opportunities to exercise their ideology. Brace and Hall (1997) show that Justices' support for death penalty is affected by competitive electoral conditions and institutional arrangements that create linkages with the political environment. With data from Bolivian trial courts, Pérez-Liñán et al. (2006) also demonstrate how career goals and hierarchical pressures can influence judges' decisions. Our paper is related to this literature by exploring how the ideological composition of French labor courts impacts judicial outcomes. Our originality is twofold. First, we provide empirical evidence on case selection and judicial decision-making based on French data on labor courts. This contrasts with the previous literature that mainly used American data. Second, we show how litigants adapt their settlement strategies to the judicial decision they anticipate.

\footnotetext{
${ }^{2}$ For surveys of Supreme Court decison-making, see Songer and Lindquist (1996); Epstein et al. (2013); Epstein and Lindquist (2016).
} 


\section{The institutional setting}

\subsection{Judges in labor courts}

French labor courts deal with individual disputes affecting labor relations in the private sector (e.g., validity of employment contracts, nullification of a dismissal, compensations to be paid, level of severance payments). ${ }^{3}$ There exist today 210 courts spread all over the territory. Each court is divided into five sections by activity (agriculture, commerce, industry, executives and diverse activities). Judges are elected within lists established by workers' unions and employers' federations every five years (at the local level, i.e. for each section of each court). Half of the 14,512 judges are elected by the employers and half by the workers. ${ }^{4}$ Lay judges can therefore be elected either in the employer or in the worker pool. First, regarding the former, the employers' federations (CGPME, MEDEF, FNSEA, UNAPL, UPA) generally propose a common list that gets the majority of the votes. There is no significant heterogeneity regarding the employers' representatives across courts. The picture for workers' unions is substantially more complex. The State recognizes five unions (for employees) as representative at a national level (These are CGT, FO, CFDT CFTC, and CFECGC). ${ }^{5}$. Each of them presents its own list during elections. CGT and FO are the two most confrontational unions, i.e. known to be the least prone to negotiate with employers' federations. According to the electoral results, the proportion of each union can sharply vary between courts and across time. This represents an interesting source of variations for our analysis. Tables A1, A2 and A3 in Appendix A show the national results of the three last election waves $(1997,2002,2008)$.

\subsection{Judicial procedure in court}

Geographical considerations entirely determine the court to which an employee has to bring his claim. ${ }^{6}$ Once a claim is opened, there is a first mandatory in-court settlement procedure to avoid litigation (called 'conciliation'). ${ }^{7}$ If parties fail to settle at this stage, the plaintiff may either withdraw the case (i.e. drop the case or settle out of court) or go to trial. The panel hearing is made up of two judges elected by employers and two judges elected by employees. They can decide on a case (accept it or reject it) or refer it to a fifth judge. The latter is a professional judge who makes the decision during a series of new hearings. ${ }^{8}$ Referals usually occur when employers and

\footnotetext{
${ }^{3}$ These courts are first level tribunals. They only deal with individual disputes. Disputes affecting collective labor relationships are dealt by ordinary civil courts (Tribunal de grande instance), only composed of professional judges.

${ }^{4}$ Judges are elected by universal suffrage by all employers and employees registered on the electoral roll (union membership is not required to vote). They are elected through proportional representation at the highest average, without splitting or preferential voting. Elections are organized by section and by college at the court level. The last election was held on December 3rd, 2008. The mandate of the judges was exceptionally extended, so as to think to a new nomination system. Elections for labor courts suffered from high levels of abstention: Only $25.48 \%$ of workers participate to the last election in 2008.

${ }^{5} \mathrm{CGT}$ is Confédération Générale du Travail/ General Confederation of Labor, CFDT is Confédération Française Démocratique du Travail / French Democratic Confederation of Labor, FO is Force Ouvrière / Worker's Power, CFTC is Confédération Française des Travailleurs Chrétiens / French Christian Workers' Confederation, and CFE-CGC is Confédération Française de l'Encadrement-Confédération Générale des Cadres / French Confederation of Professional and Managerial Staff - General Confederation of Professional and Managerial Staff. Other unions are SUD (Union Syndicale Solidaire / Trade Union Solidarity) and UNSA (Union Nationale de Syndicats Autonomes/ National Union of Autonomous Trade Unions), as well as some other independent unions.

${ }^{6}$ In other words, each court is competent for a given geographical area. If a labor conflict arises, the plaintiff cannot choose his court but has to go to the court on which his workplace depends. There are few exceptions to this general rule: for instance, workers doing work at home choose the court of the geographical area of their house.

${ }^{7}$ This stage is supervised by one judge representing employers and one judge representing employees.

${ }^{8}$ Once a decision is made either by a panel of four judges or by a panel with a professional judge, appeals can be brought before the Cour d'Appel (Chambre sociale), composed only of professional judges. Appeals against cours
} 
employees' judges fail to reach a majority decision. These features make French labor courts quite singular compared to other countries where professional judges or magistrates generally sit alongside lay judges or assessors from workers' and employers' organizations. ${ }^{9}$

Figure 1: Judicial procedure in French Labor Courts

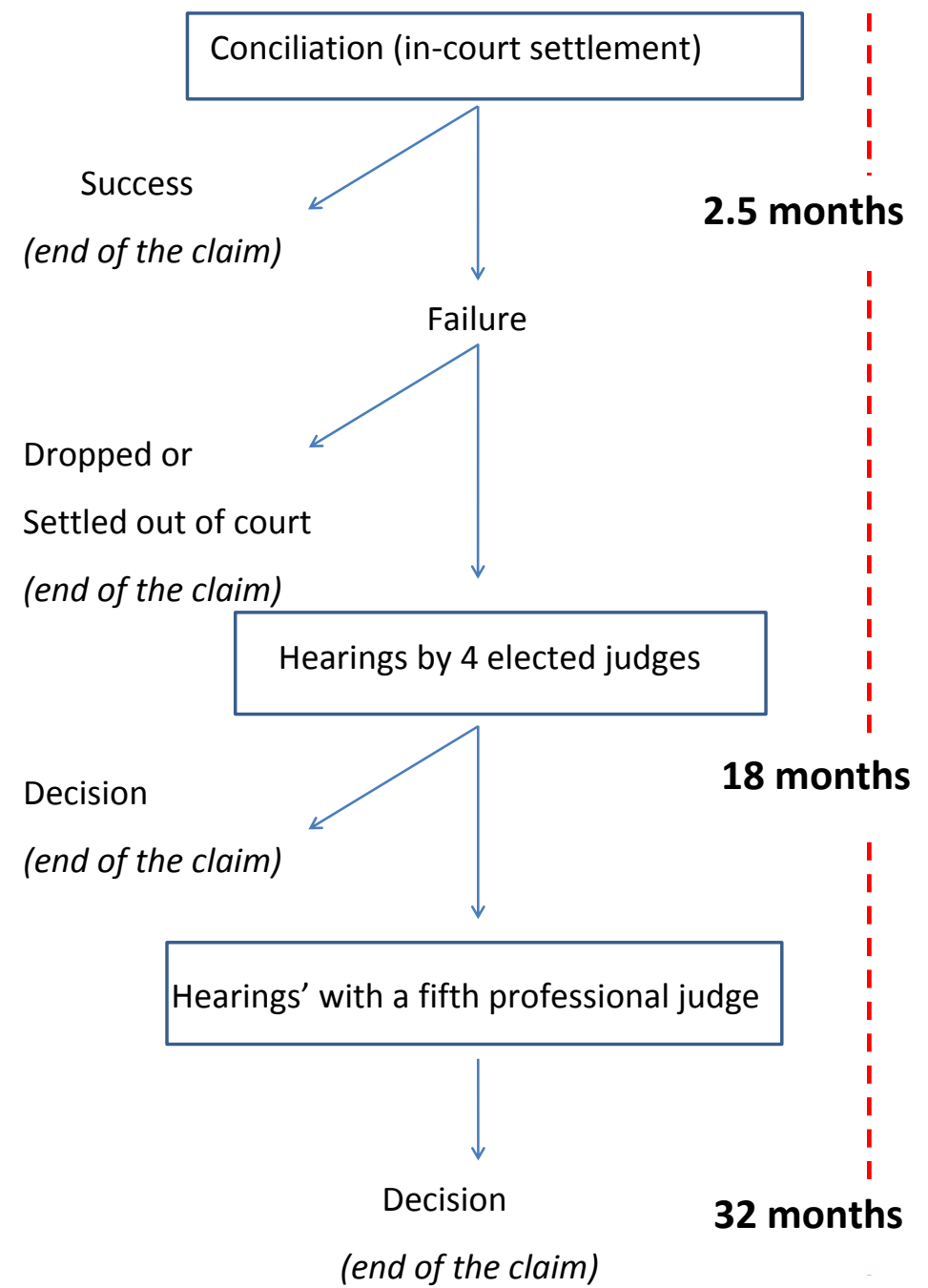

Figure 1 illustrates the judicial steps in labor courts. On average, the dispute is solved in 2.5 months when the claim is settled in court, 18.8 months when the panel of four judges hears the case, and 32 months when a professional judge intervenes (Guillonneau and Serverin (2015)). This intervention occurs on average for $15 \%$ of claims reaching trial. This means that the intervention of a professional judge represents a significant opportunity cost to get a decision on the claim. Litigants are generally well aware of the average case duration of the court they depend on. First, once a case is opened, litigants quickly have a conciliation audience. During this audience, litigants are counseled by elected judges, who must give litigants all necessary information to facilitate bargaining. During

d'appel's decisions are lodged in the Cour de cassation (Chambre sociale).

${ }^{9}$ Source: The International Labour Organization, http://www.ilo.org 
these audiences, many judges stress the long delays litigants will face to have their cases litigated in case of failure of settlement. Second, about 200,000 cases are litigated by labor courts each year. Considering that about 24 million citizens were salaried workers in 2015, employees have a great chance of knowing someone who recently litigated his/her case at labor court. Third, information about local court's delay is publicly available. The Ministry of Justice publishes indeed every year a report about the state of the courts, and online characteristics of each local court ${ }^{10}$. Fourth, prior to opening a case, employees usually contact union representatives to discuss their case. Given that unions are part of the litigation process they can easily convey information about the expected time to get a decision. All in all, delays at labor courts are a well-known phenomenon in France ${ }^{11}$, and parties are very likely to have this information prior to bargaining on the case.

The referral to a professional judge increases delays to get a final decision, which is costly for both parties. Guillonneau and Serverin (2015) show that in 2013, cases decided by a professional judge took almost twice as much time as those litigated by elected judges (i.e., 32 months against 18.8 for cases decided by elected judges). As far as the employee is concerned, longer delays are costly for at least two reasons. First, if the employee brings a case to court, he is likely to believe that he deserves a compensation. The more he waits to get this amount of money, the lower the discounted value of this compensation is for him. There is then a cost to wait a long time to get the money he thinks he is entitled to. Second, it is much harder for employees to find a new job if they have a case pending at court. Indeed, employees need to ask their new employer for a day off to go to court to defend their case. Given that employees generally have four to nine months of probation period, informing their new employer that they sued their former employer may endanger their new job. This effect is even stronger for short-term contracts, where employees have no guarantee of being reemployed. Further, referrals to professional judges is also costly for employers. First, employers need to freeze a significant amount of money (accounting provision) during the trial duration in case of conviction. The freezing of these assets represents great opportunity costs for employers, who could invest it to develop their activities. Second, the French legislation allows judges to order employers to rehire the former employee, should the firing be unfounded. Employers may therefore be reluctant to fill the position as long as the trial is not complete (Article L 1235-3 of the Labor Code). The non-occupation of the position also represents great opportunity costs for the firm. ${ }^{12}$ Third, employers face greater difficulties in the company when employees are informed that a case is pending at court. Employees who are still in the firm can be asked to testify in favor or against the former employee, which degrades the atmosphere at work. Finally, longer delays associated with the referral to a professional judge increase legal fees for both parties, since lawyers need to work more to prepare and to attend the additional hearing(s).

Given our institutional set-up, we would like test three propositions. First, because courts differ in their ideological composition, we anticipate that more polarized courts (i.e. courts with more confrontational judges) will have more difficulties to reach a common decision. This should lead to more referrals to a professional judge. Second, because the delay to get the final decision in case of referrals to a professional judge is longer, this should impact ex-ante decisions. Longer delays to get a decision mean higher costs for both parties. To avoid higher litigations costs caused by longer procedures in polarized courts, we should observe more in-court settlement and more withdrawals.

\footnotetext{
${ }^{10}$ http://www.justice.gouv.fr/statistiques.html

${ }^{11} \mathrm{http}$ ://www. lemonde.fr/societe/article/2016/04/07/1-etat-a-nouveau-inquiete-pour-des-delaisexcessifs-aux-prud-hommes_4898259_3224.html http://www. leparisien.fr/seine-saint-denis/les-prud-hommes-epingles-pour-leurs-delais-de-jugement29-03-2004-2004868372.php

${ }^{12}$ Note that damages for illegal firing is calculated based on the employee's salary at the date of firing. It does not take into account the duration of the trial in any form.
} 
This implies that the composition of cases reaching litigation should be different in polarized courts compared to the others. To sum up, we expect that:

1. A greater fraction of cases heard before polarized courts should be referred to professional judges.

2. Polarized courts should have a higher settlement and withdrawal rates.

3. Strategic settlements vis-à-vis polarized courts should change the composition of cases reaching litigation.

\section{Data}

\subsection{Stylized facts}

We consider a dataset built by the French Ministry of Justice which includes information about all cases dealt by French labor courts between 1998 and 2012. The comprehensive dataset comprises about 2.4 million cases that were addressed to French labor courts during this period. Most cases resulted from dismissed workers who challenged their former employer's decision. ${ }^{13}$

We restrict our data in four ways. First, we focus on cases in which the employee sued his (former) employer, i.e. we get rid of cases where the plaintiff was an employer. Second, because of the limited quality of the database, we exclude observations $(i)$ for which we are not able to determine how the case was terminated, $(i i)$ for cases that were joint ${ }^{14}$, or $($ iii $)$ for which essential characteristics are not reported. Third, because of data availability of the control variables, our sample restricts to courts located in metropolitan France. Fourth, to limit the unobserved heterogeneity of our data, we do not take into account cases that did not go through the standard legal process. ${ }^{15}$

Our final sample consists in 1,339,496 cases that were opened in 1998 or after, and that were terminated before the end of 2012. Figure 2 shows that the number of new cases opened each year in our dataset lies between 105,000 to 128,000. Note that only cases between 1998 and 2008 are displayed, because most cases that were opened after 2008 were not terminated in 2012. The number of new claims reached a peak in 1998 and 2002. ${ }^{16}$ The slow decrease until 2007 can be explained by good economic conditions over the period, leading to fewer dismissals (De Maillard Taillefer and Timbart (2009)). The number of cases filed is indeed connected to economic conditions: about one in four dismissed workers challenges his dismissal in labor courts (Fraisse et al. (2014)).

For each observation, we match three geographical variables: the logarithm of the regional level of GDP per inhabitant, the departmental level of unemployment ${ }^{17}$, and the composition of the

\footnotetext{
${ }^{13}$ According to the French Ministry of Justice, 8 out of 10 cases in labor courts come from dismissed workers challenging their dismissal. Other cases are about unpaid wages or unpaid compensations (De Maillard Taillefer and Timbart (2009)). More recently, Serverin and Valentin (2009) show that $91 \%$ of claims are about employees challenging personal dismissals. See Desrieux and Espinosa (2017) for more information about the state of the French labor courts.

${ }^{14}$ Several cases can be grouped (jonction) into a single case in very special circumstances. Joint cases must be nearly identical regarding both facts and legal considerations (same employer, same claims of the plaintiffs, simultaneity of suits, etc...)

${ }^{15}$ For some specific claims, there is no mandatory conciliation phase. This includes: reclassification of a temporary contract of employment, disagreement on the employer's refusal of days off, dismissal of an elected employee, suits about physical or mental injuries and suits in case of violation of individual rights.

${ }^{16}$ According to the Justice Ministry, the 2002 peak may be caused by the regulations on working time in France that were passed in 2000 (De Maillard Taillefer and Timbart (2009)).

17 Département is an administrative subdivision of the French territory. Metropolitan France is made up of 95 Départements. We then collect the unemployment rate in the Département of each court. Région is another (and
} 
Figure 2: Evolution of the number of new cases opened per year between 1998 and 2008

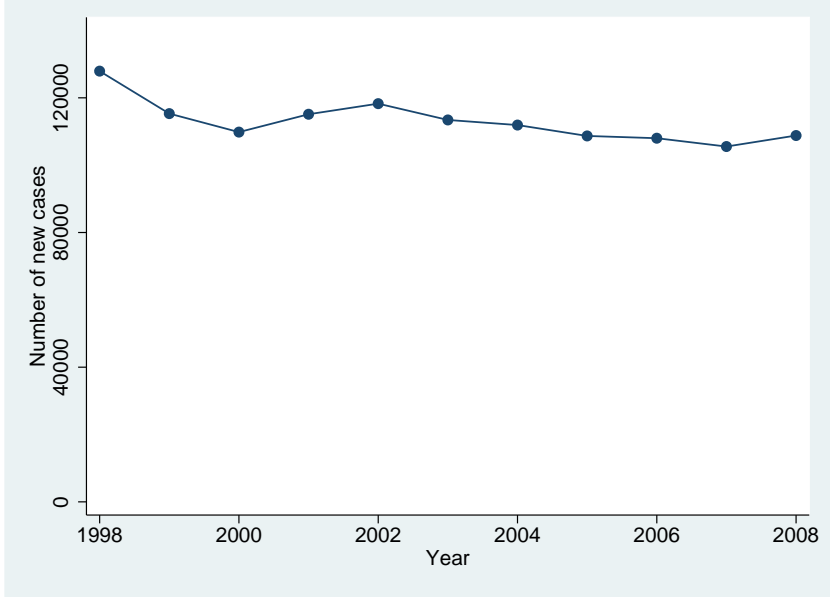

court that heard the case (we define "the composition of the court" as the union membership of the elected judges in this court). All variables were collected on the INSEE (French National Institute for Statistics) website, except the composition of the courts (Ministry of Labor). ${ }^{18}$

As recalled in subsection 3.1, judicial claims may have different outcomes: they can be either conciliated, withdrawn, decided by elected judges, or referred to a professional judge. Table 1 displays the number and the proportion of outcomes for the whole dataset. Several remarks can be made in the light of these descriptive statistics. First, the proportion of cases settled during the conciliation phase is limited but not negligible (13.47\%). This suggests that in-court settlement is a well established phenomenon in the French labor courts. Second, a great proportion of cases is not decided by elected judges nor by professional judges. Indeed, almost $24.75 \%$ of the cases disappear between the end of the conciliation period and the elected judges' decision. These withdrawn cases represent either plaintiffs who decide to drop their claims, or plaintiffs who reach an out-of-court agreement with the defendants. As the investigation shall demonstrate, we find evidence of outof-court settlement. Third, only a minority of cases is dealt by professional judges rather than by elected judges (9.28\% vs 52.5\%). However, considering that not all cases reach the panel of elected judges' (38.22\% are either conciliated or withdrawn), the proportion of cases referred to a professional judge represents $15.02 \%$ of the litigated cases.

Figure 3 displays the evolution of the structure of case outcomes over the past years. ${ }^{19}$ Several comments can be made in the light of this graph. First, one can note that plaintiffs have always been more likely to win than to loose (for both elected judges' decisions and professional judges' decisions). Second, the proportion of cases which are settled in court (conciliation) is relatively stable over time (between $9 \%$ and 13\%). Third, and most surprisingly, this graph shows a very strong substitutability between cases which are won by plaintiffs after the elected judges' decision

larger) administrative subdivision. Metropolitan France is currently made up of 22 regions. GDP is only available at this regional level.

${ }^{18}$ Note that, for each claim, these variables are collected both at the conciliation (in-court settlement) period and when the claim goes to trial (with the elected judges).

${ }^{19}$ In Figure 3, "win" (resp. "loose") refers to the probability that the case is won (resp. "lost") by the plaintiff without the intervention of a professional judge. 
Table 1: Numbers and proportions of outcomes for cases dealt between 1998 and 2012.

\begin{tabular}{lcc}
\hline \hline Case outcome & Number of cases & Proportion of cases \\
\hline Conciliation & 180,436 & $13.47 \%$ \\
\hline Withdraw & 331,562 & $24.75 \%$ \\
\hline $\begin{array}{l}\text { Acceptance of employee's } \\
\text { claims by the elected judges }\end{array}$ & 514,447 & $38.41 \%$ \\
\hline $\begin{array}{l}\text { Rejection of employee's } \\
\text { claims by the elected judges }\end{array}$ & 188,762 & $14.09 \%$ \\
\hline $\begin{array}{l}\text { Acceptance of employee's } \\
\text { claims by the professional judge }\end{array}$ & 86,888 & $6.49 \%$ \\
\hline $\begin{array}{l}\text { Rejection of employee's } \\
\text { claims by the professional judge }\end{array}$ & 37,401 & $2.79 \%$ \\
\hline \hline
\end{tabular}

and withdrawn cases. This finding suggests that withdrawn cases are cases that would have been won by the plaintiff. A possible interpretation is that a relatively important share of the withdrawn cases is due to out-of-court settlement, and not to a unilateral abandon by the plaintiff.

Figure 3: Evolution of the outcome of cases over time according to the date of opening.

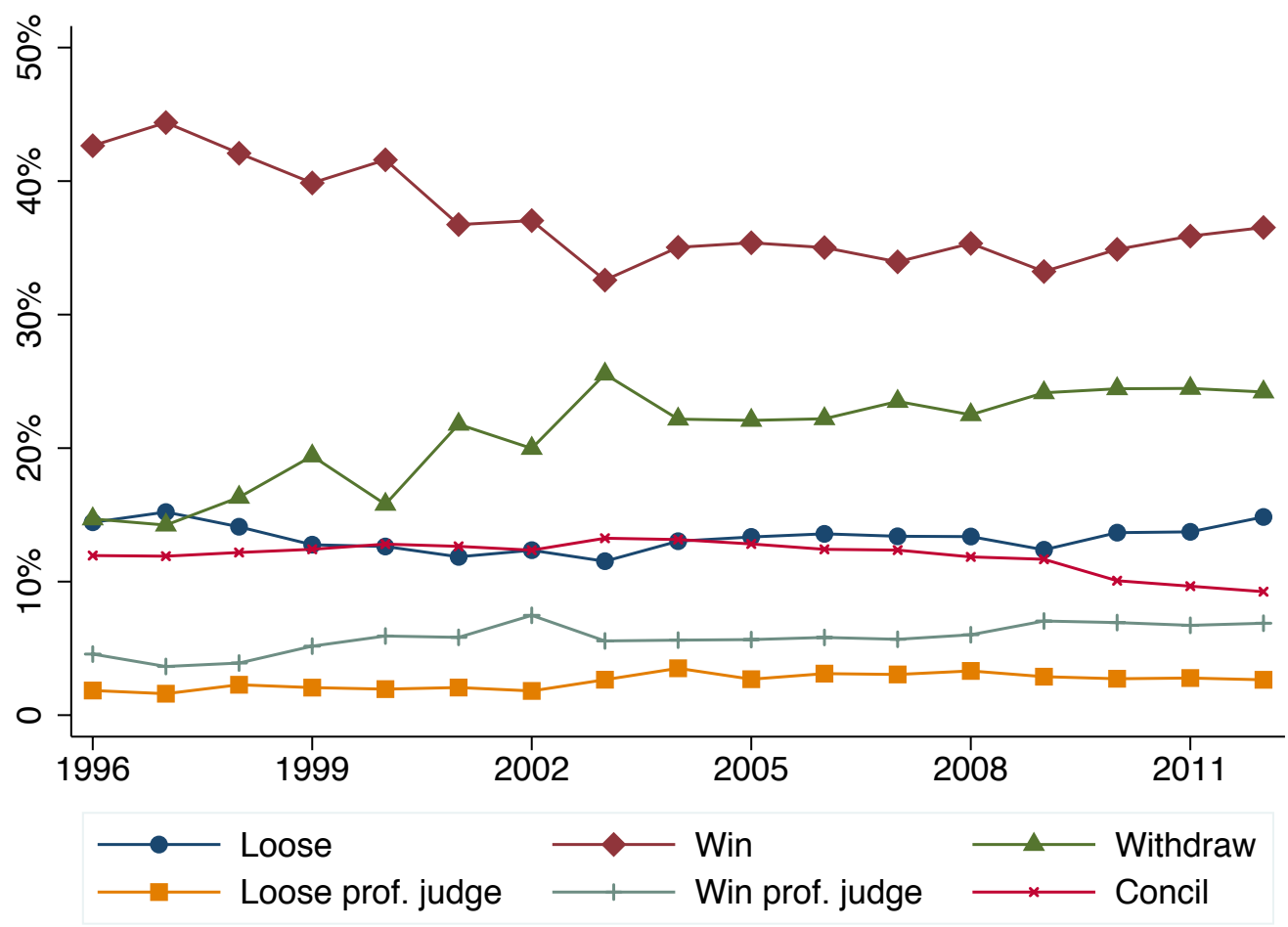

Last, table A5 in Appendix displays some statistics about the characteristics of the claims at 
each possible stage. They indicate that women represent about two-fifths of the plaintiffs. Regarding legal representation, plaintiffs tend to be more represented than defendants (26.4\% vs. $21 \%$ of cases). The greater representation of plaintiffs mainly results from the representation by unionists $(7.2 \%)$. Yet, legal representation by lawyers is lower for plaintiffs $(19.2 \%)$ than for defendants $(20.7 \%)$.

\subsection{Courts' potential bias}

We rely on three strategies to evaluate the potential ideological heterogeneity among courts, i.e. to estimate courts' potential preferences for confrontation. These strategies assume that elected judges of the same union share the union preferences for confrontation. ${ }^{20}$ First, we compute the proportion of judges from the two most confrontational unions (i.e. CGT and FO). ${ }^{21}$ We denote this measure "propConfront". Second, we estimate the preferences for confrontation of each union for the entire period, and we compute the average level of confrontation of each section of each court. ${ }^{22}$ To do so, we rely on Bayesian techniques of ideal point estimations. This allows us to represent the preferences of each union on a one-dimension axis through a single point (Appendix B). To build these points, we assume that the more a union refuses to ratify agreements with the employers at the national level, the more confrontational it is. ${ }^{23}$ Once the level of preferences (i.e. the ideal point) of each union is estimated, we compute the weighted average ideal point of each section of each court, according to the proportion of unions represented in each section. We denote this measure of the level of confrontation "confront". Third, we propose an alternative method to estimate the ideal point of each union, by allowing unions' preferences for confrontation to change over time. The full methodology used for the point estimations is presented in Appendix B. This last measure is denoted "tv_confront".

We thus obtain three measures of the risk of confrontation defined for each section of each court: propConfront, confront, tv_confront. These measures are established for each mandate of labor judges. Figures B4 and B5 show the result of the ideal point estimations that we use to construct confront and tv_confront. The two unions usually considered as the most confrontational (i.e., CGT and FO) obtain higher scores. Still, we observe that one of them (i.e., FO) is less confrontational than the other (i.e., CGT) and that this difference first increases and then shrinks over time. These results tend to support the idea that confront and $t v$ confront better capture the ideological heterogeneity of unions than the share of seats. In the following, we propose to consider the three measures to proxy ideological composition of the court, and show that most of the outcomes are robust to changes in the retained measure.

\footnotetext{
${ }^{20}$ Given the institutional context, this assumption is very likely to hold: the unions play indeed a major role in the election process since they propose the lists of candidates allowed to compete. Therefore, they usually choose candidates who share their beliefs, and elected judges need to follow their instructions to get reelected.

${ }^{21}$ These two unions - sometimes called "non-reformist unions"- are considered as more likely to refuse to negotiate with firm owners, and more prompt to organize strikes. On the contrary, the other unions ("reformist unions") are more prompt to discuss with firm owners, and to negotiate with them at both the local and the national levels (Mouriaux (2013)). We consider that non-reformist unions have stronger preferences for confrontation.

${ }^{22}$ Unlike the first method, the second one does not group unions into two homogeneous groups (confrontational or not), but allows for more heterogeneity (more or less confrontational).

${ }^{23}$ We use past inter-professional national agreements that unions had the possibility to ratify between 1996 and 2012. Inter-professional national agreements (Accords Nationaux Interprofessionnels, ANI) are country-wide agreements between worker unions and firm owners' representative organizations. [http://uimm.fr/textes-conventionnels/ accords-nationaux-interprofessionnels (Last visit: January, 2016).]
} 


\section{Empirical Analysis}

As described in section 3.2, our empirical investigation aims to test whether:

1. Polarized courts have more referrals to professional judges.

2. Polarized courts have higher settlement and withdrawal rates.

3. Strategic settlement vis-à-vis polarized courts changes the composition of cases reaching litigation.

We first investigate how the composition of courts impacts judicial decisions, and whether we observe strategic settlement in polarized courts.

\subsection{Baseline Results: parties' and judges' decisions in labor courts}

We first conduct a simple analysis to understand how the preferences for confrontation of the judges elected by the employees correlates with judicial outcomes. We account for the four possible judicial outcomes with the following variables: Conciliation ( 1 if parties settle in court, 0 if parties fail to settle in court), Withdraw (1 if parties withdraw their case, i.e. the case is either dropped or settled out of court, 0 if the case goes to full hearing, missing if parties settled at the conciliation stage), Decision2 (0 if the elected judges reject the employee's claim, 1 if the elected judges accept the claim, missing if the elected judges refer to a professional judge or if the parties settled at the conciliation stage or if the case was withdrawn), Referral (0 if the elected judges decide on the case, 1 if the elected judges refer to a professional judge, missing if the case did not reach full hearing), and Judgment ( 0 if the professional judge decides to reject the employee's claim, 1 if the professional judge decides to accept the claim, missing if the elected judges succeed in reaching an agreement or if the parties decided to settle). According to the perception of the referral to a professional judge, Decision2 can be recoded into a ternary variable Decision3 (0 if the elected judges decide to reject the plaintiff's claim, 2 if the elected judges decide to accept it, and 1 if the elected judges fail at reaching a majority decision). ${ }^{24}$

To understand how court's composition is correlated with cases' outcomes, we run a series of probit and ordered probit estimations on the above outcome variables. We include control variables defined in table A4 in Appendix A. We take into account macroeconomic factors (unemployment rate, GDP per capita) and characteristics specific to the case (plaintiff's gender, plaintiff's legal representation, defendant's legal representation). In addition, we consider the share of votes obtained by left-wing parties during the last presidential elections (with linear intrapolation), to account for business aversion in the area. We also include year and court $\times$ section fixed effects. The probit estimations on Conciliation and Withdraw further integrate the average age (number of days) of cases terminated by a decision (either from the elected judges or from the professional judges) the previous year in the same section of the same court. ${ }^{25}$ All independent variables are set at the date of the conciliation attempt for the estimation of Conciliation and to the date of the decision for the remaining variables.

\footnotetext{
${ }^{24}$ The main difference between Decision2 and Decision3 lies in the way one considers the referral to a professional judge. If one believes that it mainly results from a tie between pro-employee and pro-employer votes, Decision3 is the most suitable coding. On the other hand, if one assumes that the referral to a professional judge results from legal considerations which are orthogonal to the employee vs. employer debate or is caused by the need of legal clarification, then Decision2 is a more accurate model.

${ }^{25}$ This variable is included for Conciliation and Withdraw, because we assume that, when settling or dropping a case, litigants anticipate their outside option, i.e. litigation, and its associated costs, such as the expected duration.
} 
Table 2 summarizes the results of these estimations, which we refer to as the BASELINE model. ${ }^{26}$ Tables Online-A1, Online-A2 and Online-A3 in the on-line appendix display the results for all our measures of confrontation (propConfront, confront and $t v \_$confront). These results lead to four main observations. First, the degree of confrontation of the court is positively associated with conciliation: more cases are conciliated in courts that are dominated by confrontational unions. Second, more cases are withdrawn in these courts. The coefficients associated with the court's composition is positive and statistically significant for all probit estimations of Withdraw. Third, we observe no relation between the court's composition and the probability for an employee to win a case: this result holds for both cases actually decided by the elected judges (Decision2) and for cases decided by a professional judge (Judgement). Fourth, we observe a significant positive relationship between the level of confrontation and the probability of referral to a professional judge: cases are more likely to be referred to a professional judge in confrontational courts. The two last results explain the lack of (or the very weak) significance level associated with the court's composition in Decision3.

Altogether, these results show that confrontational courts are associated with more referrals to professional judges, which may increase delays and, in fine, make labor courts costlier for litigants. Section 5.3 further investigates whether this effect is driven by selection effects, given that in-court settlement and withdrawal are also affected by court composition.

Result 1. We observe more in-court settlement, withdrawals and referrals to a professional judge in courts where confrontational unions are the most represented.

\footnotetext{
${ }^{26}$ We choose to display the coefficients of the probit estimations and not the marginal effects as it is usually done in Law and Economics when stuying judges' decisions. For instance, Garoupa et al. (2011) state: "Usually with these types of econometric models, we should consider the sign and not the magnitude of the estimated coefficients. In other words, we do not assess quantitatively the marginal impact of each explanatory variable on the probability of a judge voting for constitutionality; rather there is only a qualitative assessment (the sign of the coefficient)."
} 
Table 2: Results of probit and ordered probit estimations of the impact of the court's composition at each decision step. BASELINE Model.

\begin{tabular}{|c|c|c|c|c|c|c|c|}
\hline Model & $\begin{array}{l}\text { Variable } \\
\text { Technique }\end{array}$ & $\begin{array}{c}\text { Conciliation } \\
\text { Probit }\end{array}$ & $\begin{array}{c}\text { Withdraw } \\
\text { Probit }\end{array}$ & $\begin{array}{c}\text { Decision3 } \\
\text { Ordered Pr. }\end{array}$ & $\begin{array}{c}\text { Decision2 } \\
\text { Probit }\end{array}$ & $\begin{array}{c}\text { Referral } \\
\text { Probit }\end{array}$ & $\begin{array}{c}\text { Judgement } \\
\text { Probit } \\
\end{array}$ \\
\hline (1) & propConfront & $\begin{array}{c}0.0502^{* * *} \\
(2.861)\end{array}$ & $\begin{array}{c}0.364^{* * *} \\
(23.00)\end{array}$ & $\begin{array}{c}-0.0358^{* *} \\
(-2.056)\end{array}$ & $\begin{array}{l}-0.0216 \\
(-1.042)\end{array}$ & $\begin{array}{c}0.0898^{* * *} \\
(4.020)\end{array}$ & $\begin{array}{l}0.0102 \\
(0.186)\end{array}$ \\
\hline (2) & confront & $\begin{array}{c}0.00565^{*} \\
(1.731)\end{array}$ & $\begin{array}{c}0.0604^{* * *} \\
(20.39)\end{array}$ & $\begin{array}{c}0.00242 \\
(0.745)\end{array}$ & $\begin{array}{l}0.00611 \\
(1.592)\end{array}$ & $\begin{array}{c}0.0104^{* *} \\
(2.492)\end{array}$ & $\begin{array}{c}0.00239 \\
(0.233)\end{array}$ \\
\hline (3) & tv_confront & $\begin{array}{c}0.0112^{* * *} \\
(2.867)\end{array}$ & $\begin{array}{c}0.0795^{* * *} \\
(22.50)\end{array}$ & $\begin{array}{r}-0.00437 \\
(-1.125)\end{array}$ & $\begin{array}{c}0.000695 \\
(0.151)\end{array}$ & $\begin{array}{c}0.0221^{* * *} \\
(4.407)\end{array}$ & $\begin{array}{c}0.00331 \\
(0.269)\end{array}$ \\
\hline & Court $\times$ Section FE & Yes & Yes & Yes & Yes & Yes & Yes \\
\hline & Year FE & Yes & Yes & Yes & Yes & Yes & Yes \\
\hline & Controls & Yes & Yes & Yes & Yes & Yes & Yes \\
\hline & $\mathrm{N}$ & $1,343,494$ & $1,160,938$ & 838,895 & 703,455 & 840,020 & 125,613 \\
\hline
\end{tabular}

Significance level: ${ }^{* * *}$ significant at $1 \%$ level; ${ }^{* *}$ significant at $5 \%$ level; ${ }^{*}$ significant at $10 \%$ level.

Z-statistics in parentheses. Robust standard errors. 


\subsection{Endogeneity concerns: lower bond estimation}

The above findings show that courts' composition is correlated with case outcomes. One possible explanation is that our estimations do not correctly capture the causal impact of the courts' composition. Indeed, since half of the judges are elected by workers, it is likely that a common factor, that we refer to as the population's preferences, affects both judges' election and the litigants' strategies. Changes in the population's preferences may be correlated with changes in strategies in court such that coefficients associated with the composition of the courts capture both the causal impact of judges and the latent phenomenon that determines this composition.

More technically, if the population's preferences affect both choices (strategies at court determining the final outcome of a claim and elections of judges), the above results would suffer from an omitted variable bias. Using IV techniques or quasi-natural experiments would be the most suitable way to deal with such endogeneity. The first solution would however require to find instruments that affect the voting outcomes but not the preferences of the voters. Since no such instrument is available, we exclude the use of instrumental variables. The second solution would require legislative or administrative changes, which would directly affect the courts' composition. Since no such exogenous shock exists, we rely on a second-best strategy. ${ }^{27}$

Our variable of interest is the proportion of confrontational judges sitting at court. This variable is a priori positively correlated with the confrontational attitude of the population given the electoral process. The main risk is therefore that the proportion of confrontational judges partially captures the employees' confrontational attitude. The latter is mostly likely to affect outcomes when employees have a decision power, namely at the Conciliation and the Withdraw stages. The general model for the latent utility of these two outcomes writes:

$$
y_{i}=\alpha+\beta_{1} \text { judgesConfront }_{i}+\beta_{2} \text { popConfront }_{i}+\gamma X_{i}+u_{i}
$$

where judgesConfront would capture the impacts of the judges' affiliation to confrontational unions and popConfront would capture the preferences of the population for confrontation. By decomposing popConfront into two parts, i.e. one correlated with the proportion of confrontational judges and one uncorrelated, we obtain: popConfront C $_{i}=\rho$ judgesConfront $i+\epsilon_{i}($ with $\rho>0)$. The estimated specification is equal to:

$$
y_{i}=\alpha+\beta_{1}^{\prime} \text { judgesConfront }_{i}+\gamma X_{i}+\left(u_{i}+\epsilon_{i}\right)
$$

with $\beta_{1}^{\prime}=\beta_{1}+\rho \beta_{2}$, or equivalently $\beta_{1}=\beta_{1}^{\prime}-\rho \beta_{2}$.

More confrontational employees are, by definition, less likely to conciliate and less likely to withdraw their case. It follows that $\beta_{2}>0$ for both the Conciliation and the Withdraw decision nodes. Thus, the estimated coefficient $\beta_{1}^{\prime}$ is lower than the coefficient $\beta_{1}$. In other words, the above results are lower-bond estimates of the real impact of the proportion of confrontational judges on

\footnotetext{
${ }^{27}$ The most natural proxy for the omitted variable would be the proportion of votes devoted to non-reformist unions. Let us recall that seats are assigned through a proportional election at the highest average, so that there can be a slight difference between the percentage of votes and the percentage of seats each union gets. In our dataset, the empirical correlation between the proportion of seats and the share of votes devoted to non-reformist unions is equal to 0.917 for the conciliation stage and to 0.914 for the judgment stage. The percentage of votes would capture the preferences of the population while the proportion of seats would capture the real impact of elected judges. However, the inclusion of the percentage of votes for the judges' elections is impossible because the election process is too proportional, and therefore generates too much collinearity.
} 
the conciliation and withdraw decisions. The above estimations, which yield a positive coefficient for the two stages, seem therefore not threatened by the omitted variable bias.

\subsection{Selection effects: controlling for anticipations}

The BASELINE estimation shows that more confrontational courts are associated with more incourt settlement, more withdrawals and more referrals to a professional judge. We now propose to investigate the selection effects resulting from strategic settlement. More precisely, our goal is to determine whether the selection of cases sent to trial is different in courts held by confrontational unions compared to the other courts. Indeed, some unobservables may influence the decision to conciliate or withdraw a case, and then influence the composition of the claims sent to courts. ${ }^{28}$ In other words, confrontational and non-confrontational courts could face different cases when the four elected judges have to make a decision. The probability to accept or reject a case could come from this difference in composition instead of ideological predispositions. We then have to control for case selection to see whether the decision to accept or reject a case - or to refer it to a professional judge- is driven by this composition effect.

To investigate these selection effects, we estimate a triprobit model, which consists of two selection steps (Conciliation and Withdraw). Indeed, cases heard by the panel of judges have been through two selection stages: the decision to conciliate and the decision to withdraw the case. We thus estimate a triprobit model, in which the first step is conciliation, the second step is withdrawal and the third step is the elected judges' decision to accept the plaintiff's claims or to reject them (Decision2). This model estimates the correlation coefficients between the unobservables, which allows to infer characteristics about the cases that are conciliated and withdrawn. In the following, we call evidence the unobservables that increase the probability that a plaintiff wins his/her case. ${ }^{29}$ Our focus will be on the correlation between the error terms of Conciliation, Withdraw and Decision2 to understand whether unobservables hidden in the error terms determine both settlement decision (through conciliation or withdrawal) and acceptance in court. In other words, the correlation coefficient provides information about the types of cases that are conciliated or withdrawn (regarding the probability of being accepted if they would have not been conciliated or withdrawn). Alternatively, we estimate another triprobit model where the last step is the decision to refer to a professional judge (Referral). This allows us to understand whether unobservables determine both settlement and the decision to refer to a professional judge. Tables 3 and 4 display the results of these two estimations.

Let us first interpret the impacts of confrontational courts on the way cases are settled or decided. First, controlling for the first selection step (conciliation), the increase in withdrawals observed in courts held by confrontational unions remains. The coefficient associated with the proportion of confrontational judges is indeed significant at $1 \%$ level in both tables. Cases are then on average more conciliated in confrontational courts than in other courts. Second, controlling for the two selection steps (conciliation and withdraw), confrontational courts are not significantly more or less likely to decide in favor of the plaintiffs (the coefficient associated with Decision2 is not significant). Third, the higher proportion of referrals to professional judges in confrontational courts is artificially driven by the selection steps. The coefficient associated with the proportion of confrontational judges in the Referral step is not significant anymore. This means that controlling for case selection, judges in confrontational courts do not have a higher propensity to refer to the professional judge. They do so only because the cases they hear are per se more likely to go to referral.

\footnotetext{
${ }^{28}$ These unobservables were hidden in the error terms of our previous estimations.

${ }^{29}$ It includes all factors not present in our dataset that make an employee more likely to win his/her case.
} 
Result 2. The ideological composition of labor courts does not significantly impact the decision made on cases nor the decision to refer to a professional judge.

We now consider why cases are more conciliated in confrontational courts. Our estimations show that conciliated cases would have been more likely to be lost by employees. Indeed, the correlation coefficient between the error terms of Conciliation and Decision2 is negative ans statistically different from zero $\left(\hat{\rho}_{c d}=-0.284, p<1 \%\right)$. This indicates that some unobserved factors driving toward more conciliation would have decreased the chances of a favorable decision for the employee. To put it differently, conciliated cases would have had lower chances of winning for the employee. In the same way, the positive correlation coefficient $\left(\hat{\rho}_{w d}=0.168, p<1 \%\right)$ means that unobservables that increase the decision to withdraw the case also increase the probability of acceptance. This allows us to get some information on the "quality" or evidence characterizing the cases. Our interpretation is that withdrawn cases are "good" cases for the plaintiff. Cases withdrawn by plaintiffs are very favorable to them (because they would have won them). Since it is unlikely that employees withdraw favorable cases, they must be settled outside the court. In the same way, conciliated cases are "bad" cases for the plaintiffs because they would have lost in court.

Result 3. Withdrawn cases would have been won in court which suggests that they are settled out of court.

Last, we interpret our results regarding the decision to refer to a professional judge. The correlation coefficient between the conciliation step and referral is significant and positive $\left(\hat{\rho}_{c, r e f}=0.927\right.$, $p<1 \%$ ). Conciliated cases would have been more likely to be referred to a professional judge. However, withdrawn cases are less likely to be sent to a professional judge $\left(\hat{\rho}_{w, r e f}=-0.641, p<1 \%\right)$. As a consequence, the higher proportion of cases referred to professional judges in confrontational courts comes from a selection effect. In these courts, more cases are conciliated but more cases are also withdrawn. Since there is on average more withdrawn cases than conciliated cases, more cases that would not have been referred to a professional judge are sent to court. In other words, the proportion of cases sent to court that are likely to be referred to a professional judge is higher in confrontational courts than in the other courts. This explains why we find a positive and significant coefficient for Referrals in our preliminary analysis, and why this coefficient is no longer significant in our triprobit estimations. ${ }^{30}$

Result 4. The higher proportion of referrals in confrontational courts mainly comes from a selection effect.

Building on results 1 and 4, we can explain why conciliation is more frequent in confrontational courts. Anticipating more referrals to professional judges, the procedure is on average longer (see Figure 1) in confrontational courts once the claim is heard by the elected judges. This gives more incentives to litigants to settle their cases. Cases with clear evidence for the plaintiff are withdrawn to be settled out of court. Claims unfavorable to the plaintiffs are rather conciliated. Mixedevidence claims are sent to trial. On average, confrontational courts have a higher proportion of mixed-evidence claims at trial (i.e. heard by the elected judges) since there are more conciliations

\footnotetext{
${ }^{30}$ The absence of statistical significance for Referrals itself is not sufficient to conclude that the Baseline results are solely driven by a selection effect. It might be indeed that the variance of the estimated coefficient becomes larger. However, the coefficient associated to Referral was equal to $0.0898(p<1 \%)$ in the Baseline results, and is equal to $0.027(p>10 \%)$ in the triprobit estimation. In other words, the magnitude of the average estimated coefficient has been divided by 3.3 , which tends to confirm the hypothesis of a selection effect.
} 
Table 3: Results of the triprobit estimations of the impact of the court's composition on decision steps.

\begin{tabular}{|c|c|c|c|}
\hline Step & Conciliation & Withdraw & Decision2 \\
\hline propConfront & $\begin{array}{c}0.035^{*} \\
(1.72)\end{array}$ & $\begin{array}{c}0.346^{* * *} \\
(19.00)\end{array}$ & $\begin{array}{l}-0.0001 \\
(-0.00)\end{array}$ \\
\hline$\rho_{c w}$ & & $\begin{array}{c}-0.685^{* * *} \\
(-39.14)\end{array}$ & \\
\hline$\rho_{c d}$ & & $\begin{array}{c}-0.284^{* * *} \\
(-7.69)\end{array}$ & \\
\hline$\rho_{w d}$ & & $\begin{array}{c}0.168^{* * *} \\
(3.65)\end{array}$ & \\
\hline Section $\times$ Court FE & & Yes & \\
\hline Year FE & & Yes & \\
\hline Controls & & Yes & \\
\hline Observations & & 905,125 & \\
\hline Log-Likelihood & & $-1,123,310.9$ & \\
\hline
\end{tabular}

First step: conciliation; second step: withdraw; third step: Elected judges' decision to accept the employee's claim.

$\rho_{c w}$ : correlation between the error terms of the conciliation step and the withdraw step.

$\rho_{c d}$ : correlation between the error terms of the conciliation step and the elected judges' decision to accept the employee's claim.

$\rho_{w d}$ : correlation between the error terms of the withdraw step and the elected judges' decision to accept the employee's claim.

Significance level: *** significant at $1 \%$ level; ** significant at $5 \%$ level;

* significant at $10 \%$ level.

Z-statistics in parentheses.

and more withdraws. The litigated claims are more frequently referred to a professional judge because of their complexity. This makes the average case duration (to get a final decision) longer once the case is sent to trial. ${ }^{31}$ This explains in turn why parties settle at the early stage of the process. There is then a self-fulfilling behavior of the parties: because they anticipate more referrals in confrontational courts, they settle earlier in the process, and send the most complex claims to court. These claims need more frequently the intervention of a professional judge making the average duration to get a final decision longer.

\footnotetext{
${ }^{31}$ The impact of confrontational courts on the average case duration is however unclear. On the one hand, the average duration of litigated cases (i.e. cases heard by the judges) is longer in these courts because of more frequent referrals to professional judges. On the other hand, we observe more settlements and withdrawals in these courts, which shortens the duration to get the dispute solved. On average, the final impact of confrontational judges on case duration (i.e. the average duration of all cases brought to courts) is determined by these two opposite effects.
} 
Table 4: Results of the triprobit estimation of the impact of the court's composition on decision steps.

\begin{tabular}{cccc}
\hline \hline Step & Conciliation & Withdraw & Referral \\
\hline & & & \\
propConfront & .0196 & $.334^{* * *}$ & .027 \\
& $(1.06)$ & $(19.08)$ & $(1.49)$ \\
$\rho_{c w}$ & & $-.691^{* * *}$ & \\
& & $(-59.74)$ & \\
$\rho_{c, r e f}$ & $0.927^{* * *}$ & \\
& & $(226.09)$ & \\
$\rho_{w, r e f}$ & $-0.641^{* * *}$ & \\
& $(-42.93)$ & \\
& & & \\
Section $\times$ Court FE & & Yes & \\
Year FE & Yes & \\
Controls & Yes \\
Observations & & \\
Log-Likelihood & $1,006,717$ & \\
\hline \hline
\end{tabular}

First step: conciliation; second step: withdraw; third step: Referral to a professional judge.

$\rho_{c w}$ : correlation between the error terms of the conciliation step and the withdraw step.

$\rho_{c, r e f}$ : correlation between the error terms of the conciliation step and the decision to refer to a professional judge.

$\rho_{w, r e f}$ : correlation between the error terms of the withdraw step and the decision to refer to a professional judge

Significance level: ${ }^{* * *}$ significant at $1 \%$ level; ${ }^{* *}$ significant at $5 \%$ level; * significant at $10 \%$ level.

Z-statistics in parentheses. 


\section{Discussion on the volume of litigation}

We now investigate whether the volume of litigation changes across courts. We propose to discriminate between three situations: (i) more confrontational courts might attract more cases (case inflation), (ii) fewer cases (case deflation), or (iii) might not change the amount of opened claims (case stagnation).

To distinguish between these scenarios, we proceed in two steps. First, we collapse the data to obtain a panel dataset that contains the number of cases opened at each section of each labor court per year. We use these data to measure the extent to which the demand for litigation is correlated with the composition of the court (subsection 6.1). However, such an investigation might also suffer from an omitted variable bias: Changes in the demand for litigation might indeed result from changes in the workers' preferences, which may also determine the number of confrontational elected judges. To deal with such a problem, we also explore the impact of the changes of the courts' composition on a limited time-span where preferences can be assumed to be constant (subsection $6.2)$.

\subsection{Correlation between demand for litigation and confrontation}

To start with, we collapse the dataset presented above to obtain for each section of each labor court the number of new cases per year $(y c)$ and the number of new cases per elected judge $(y c p j)$. We then estimate by OLS the relationship between the proportion of the most confrontational elected judges (CGT and FO) and the volume of the demand for litigation. Our regressions include time and spatial (at the court's section level) fixed effects and control variables (GDP, unemployment). We explore several specifications.

First, we run the estimation from 1998 to 2012 for the number of new cases per year, but we exclude some courts after 2008. ${ }^{32}$ Second, we run the estimation for the number of new cases per elected judge for all years and all labor courts. ${ }^{33}$ The estimated coefficients associated to the proportion of elected judges from confrontational unions are displayed in table 5 .

Table 5 does not yield decisive evidence with regard to the correlation between the composition of the court and the volume of litigation. Although all specifications give a positive coefficient, few of them yield a coefficient statistically different from 0 at $10 \%$ and none of them at $5 \%$. There is then no convincing evidence of the impact of labor courts' composition on the demand for litigation. In other words, confrontational courts do not attract more or fewer cases.

\subsection{Stable preferences, confrontation and the demand for litigation}

One of the main challenges to capture the effect of changes in the courts' composition on the demand for litigation is to control preferences that could affect both the composition of the court and the volume of litigation (i.e. the conflict rate). Said differently, it could be that the preferences of a population in a given geographical area influence both electoral choices and the decisions to bring

\footnotetext{
${ }^{32}$ In 2008, the judiciary map was reformed (Decree $n^{0}$ 2008-514 of May 29th, 2008): some labor courts were removed, while others took over their competency. The courts that have expanded their geographical competency have received a great amount of new claims after this reform depending on the size of the removed courts (Espinosa et al. (2017b),Espinosa et al. (2017a)). We therefore exclude data after 2008 for the courts that expanded their competency.

${ }^{33}$ All elected judges from the removed courts were reaffected in the courts that took over removed courts' geographical competency. The number of elected judges has not been affected by the reform. Let us precise that the reform did not modify the composition of receiving courts. The transfer of cases and elected judges' positions occur at the same time as the elected judges elected in 2008 took their duties.
} 
Table 5: Estimated effect of the level of confrontation on the demand for litigation.

\begin{tabular}{cccccc}
\hline \hline & \multicolumn{2}{c}{ Number of claims } & & \multicolumn{2}{c}{ Number of claims per elected judge } \\
\cline { 2 - 3 } \cline { 5 - 6 } propConfront & Pooled OLS & Within & & Pooled OLS & Within \\
\hline \multirow{2}{*}{ confront } & 20.863 & 20.863 & & 9.188 & $9.188^{*}$ \\
& $(1.24)$ & $(1.29)$ & & $(1.6)$ & $(1.67)$ \\
tv_confront & 4.279 & $4.279^{*}$ & & 1.178 & 1.178 \\
& $(1.63)$ & $(1.70)$ & & $(1.29)$ & $(1.34)$ \\
& $5.632^{*}$ & $5.632^{*}$ & & 1.621 & 1.621 \\
\hline \hline
\end{tabular}

Statistical significance: ${ }^{*} \mathrm{p}<0.1{ }^{* *} \mathrm{p}<0.05$; ${ }^{* * *} \mathrm{p}<0.01$., Robust Z-statistics in parentheses.

cases to court. The correlation between the composition of a court (following the electoral votes) and the number of litigated cases would be caused by a common external factor: the preferences of a population in a geographical area. To understand the real impact of the court's composition on the number of new cases, we try to isolate the preferences of the population. To that end, we consider changes in the demand for litigation within a one-year span (6 months before and 6 months after the elections). We assume that, within this period, preferences are relatively stable.

We first consider the change of elected judges in 2003, namely when the elected judges who were elected on December, 11th 2002 took office and replaced those elected in 1996. We compute the amount of cases opened at each section of each court from June to November 2002 and those from January to June 2003. We apply a similar strategy for the 2008 election: We compute the sum of all cases opened between June and November 2008 and those opened between January 2009 and June 2009. We then compute the growth rate of cases before/after election. We compute the change in the courts' preferences for confrontation ( $\Delta$ propConfront, $\Delta$ confront, $\Delta$ tv_confront), the change of unemployment, and the growth rate of log of the GDP per inhabitant.

Table 6 displays the correlation coefficients between the growth rates of the number of claims and the changes in the proportion of confrontational elected judges. Correlation coefficients are computed per section. ${ }^{34}$ In order to control for possible changes in the employment market, we also control for unemployment and GDP changes. OLS coefficients of this first-difference estimation are displayed in table 7 . Tables 6 and 7 show a common pattern: on overall, we do not detect any significant increase nor decrease in the volume of the demand for litigation following an increase in the court's confrontation level. Table 6 detects a positive increase for the executives' section, but this increase holds for 2003 only and is not significant when controlling for the situation of the employment market. Both tables detect a decrease in the demand for litigation for the section of diverse activity. Controlling for the employment market increases the significance of the correlation (table 7). This result does however not hold for the 2003 replacement. On the whole, this evidence tends to support the case stagnation hypothesis mentioned above: The demand for litigation is independent from the level of confrontation of a court.

Result 5. The ideological composition of the court does not impact the number of new cases brought to labor courts.

\footnotetext{
${ }^{34}$ Note that, because of the 2008 reform described in a previous footnote, the analysis of the 2009 replacement limits to courts that have not been affected by the reform.
} 
Table 6: Correlation between the growth rate of the number of new claims and changes in the composition of the courts per type of section.

\begin{tabular}{ccccccccc}
\hline \hline & \multicolumn{3}{c}{ January 2003 } & & \multicolumn{3}{c}{ January 2009 } \\
\cline { 2 - 3 } & $\Delta$ propConfront & $\Delta$ confront & $\Delta$ tv_confront & $\Delta$ propConfront & $\Delta$ confront & $\Delta$ tv_confront \\
\hline Agriculture & 0.088 & 0.125 & 0.119 & & 0.025 & 0.022 & 0.019 \\
& $(0.29)$ & $(0.135)$ & $(0.154)$ & & $(0.815)$ & $(0.835)$ & $(0.86)$ \\
Commerce & -0.062 & -0.097 & -0.076 & & -0.045 & -0.056 & -0.048 \\
& $(0.32)$ & $(0.117)$ & $(0.222)$ & & $(0.587)$ & $(0.498)$ & $(0.564)$ \\
Diverse Act. & 0.007 & 0.022 & 0.024 & & $-0.154^{*}$ & $-0.2^{* *}$ & $-0.17^{*}$ \\
& $(0.936)$ & $(0.785)$ & $(0.769)$ & & $(0.091)$ & $(0.027)$ & $(0.06)$ \\
Executives & $0.132^{* *}$ & $0.12^{*}$ & $0.126^{* *}$ & & 0.004 & 0.104 & 0.066 \\
Industry & $(0.037)$ & $(0.057)$ & $(0.046)$ & & $(0.966)$ & $(0.208)$ & $(0.424)$ \\
& -0.001 & -0.03 & -0.019 & & 0.047 & -0.02 & 0.007 \\
& $(0.986)$ & $(0.626)$ & $(0.758)$ & & $(0.571)$ & $(0.812)$ & $(0.934)$ \\
\hline \hline
\end{tabular}

Significance level: ${ }^{* * *}$ significant at $1 \%$ level; ** significant at $5 \%$ level; ${ }^{*}$ significant at $10 \%$ level.

$\mathrm{P}$-values in parentheses 
Table 7: OLS estimates of the impact of changes in the composition of the courts on the demand for litigation per type of section.

\begin{tabular}{ccccccccc}
\hline \hline & \multicolumn{3}{c}{ January 2003 } & & \multicolumn{3}{c}{ January 2009 } \\
\cline { 2 - 3 } \cline { 7 - 8 } & $\Delta$ propConfront & $\Delta$ confront & $\Delta$ tv_confront & & $\Delta$ propConfront & $\Delta$ confront & $\Delta$ tv_confront \\
\hline Agriculture & 1.406 & 0.341 & 0.386 & & 0.057 & 0.05 & 0.056 \\
& $(0.352)$ & $(0.266)$ & $(0.271)$ & & $(0.967)$ & $(0.801)$ & $(0.845)$ \\
Commerce & -0.381 & $-0.1^{*}$ & -0.096 & & -0.85 & -0.206 & -0.221 \\
& $(0.201)$ & $(0.057)$ & $(0.124)$ & & $(0.171)$ & $(0.343)$ & $(0.355)$ \\
Diverse Act. & 0.041 & 0.018 & 0.024 & & $-0.527^{* *}$ & $-0.117^{* * *}$ & $-0.126^{* *}$ \\
& $(0.907)$ & $(0.708)$ & $(0.717)$ & & $(0.03)$ & $(0.008)$ & $(0.02)$ \\
Executives & 0.746 & 0.118 & 0.148 & & -0.082 & 0.105 & 0.078 \\
Industry & $(0.119)$ & $(0.146)$ & $(0.137)$ & & $(0.842)$ & $(0.164)$ & $(0.322)$ \\
& -0.04 & -0.046 & -0.035 & & 0.312 & -0.03 & 0.01 \\
& $(0.949)$ & $(0.705)$ & $(0.794)$ & & $(0.448)$ & $(0.822)$ & $(0.941)$ \\
\hline \hline
\end{tabular}

Significance level: ${ }^{* * *}$ significant at $1 \%$ level; ${ }^{* *}$ significant at $5 \%$ level; ${ }^{*}$ significant at $10 \%$ level.

Robust standard errors, $\mathrm{P}$-values in parentheses 


\section{Conclusion}

Settlement and judicial decision-making have drawn a large attention in the economic literature, but much remains to be investigated to have a comprehensive view of dispute resolution. We summarize here the main insights of our paper, and our contribution to this literature.

French labor courts: an interesting setting. French labor courts are specialized courts with a mandatory settlement procedure. They allow the collection of data on in-court settlement and on the parties' decisions to maintain or withdraw their case if settlement has failed. Judges are elected at the court level within lists established by different unions. We use the heterogeneity in the composition of each court to distinguish between courts held by confrontational unions and the others. Last, confrontation between judges is expected to increase litigation costs. This unique setting allows us to empirically investigate how the ideological composition of court impacts the strategies of the parties.

Main Results. We find that (i) judges' ideological predispositions have no significant impact on litigation outcomes once controlling for case selection, but (ii) differences among courts result from strategic settlement. When litigants observe longer judicial procedures (because of more frequent referrals to professional judges), they settle more frequently. Our triprobit estimations show that settlement is mainly chosen for clear-evidence claims, i.e. claims that are the most likely to win or to loose at court. The most difficult conflicts (for which the probability of a plaintiff's victory is harder to anticipate) are sent to the judges. This generates, on proportion of litigated cases, more referrals to professional judges and longer procedures. By anticipation, this increases the parties' incentives to settle in court or withdraw their case.

Scope of our results. Our work bears on French labor courts. Yet, our results lead to more far-reaching conclusions about litigants' behavior. First, we show that in-court settlement and outof-court settlement correspond to two different types of cases. Our triprobit estimations suggest that claims in favor of the plaintiff are more easily withdrawn (which suggests out-of-court settlement) while claims with little evidence for the plaintiffs are rather settled in-court. This emphasizes the usefulness of in-court settlement as a first step of any litigation process. It can help to solve cases that could have not been settled out of court. Second, our results show that litigants' decision to settle a case depends on the anticipated case duration. Policies aiming at reducing delays may then have counter-intuitive effects and lead to an increase in the average case duration. If parties anticipate shorter delays for claims heard by judges, they can be more reluctant to settle in court. Instead, they can prefer to send cases to trial. With more cases heard by judges, treatment delays can become longer even if each case is solved more rapidly. Reforms aiming to reduce procedures for cases heard in court should then be led carefully.

Our results question the litigants' rationality. Indeed, the triprobit estimations show that the higher proportion of referred cases anticipated by litigants result from their very own behavior (i.e., the settlement of the least complex cases). To some extent, litigants are quite rational as they settle more frequently in court with longer delays (i.e. confrontational courts). Yet, they seem unable to anticipate that this longer duration comes from a selection effect (the most complex cases are litigated). The information they rely on is probably the average duration to get a final decision.

Contribution to the literature. Our work adds to the literature focusing on the determinants of settlement and case selection. Our empirical evidence suggests that mixed-evidence cases are 
selected to trial, and cases with clearer evidence are rather settled. Our results rather support Priest and Klein's proposition, whereby the most complex cases are the most likely to be litigated. We also show that the anticipation of case duration plays a role on the settlement decision. The previous literature has investigated how the field of laws (Gross and Syveryd (1991); Eisenberg and Lanvers (2009)), the characteristics of the judge (Berlemann and Christman (2016)) the characteristics of the case (Kaplan et al. (2008)), or the value of the claims (Lederman (1999); Huang et al. (2010)) impact the settlement decision. We prove here that the anticipated case duration also matters. To our knowledge, this has not been documented up to now.

We also contribute to the literature on the ideological composition of courts (Segal and Spaeth (1993, 1996); Epstein et al. (2013)). Our results show that ideology does not impact the final outcome of cases. This contrasts with a large literature mainly relying on American data and suggesting that judicial vote is correlated with political preferences of judges. One explanation for the absence of significant impact of ideological predispositions in our setting may come from the institutional rules governing the procedure. Since (i) decisions are made by a panel of four elected judges (two representatives of employers and two representatives of employees) and (ii) a fifth professional (non-elected) judge makes the decision if necessary, there is no room for a decision based only on ideological criteria.

\section{Acknowledgments}

The authors would like to thank two anonymous referees and Claude Fluet, Nuno Garoupa, Bruno Deffains, Daniel Klerman, Mathieu Lefebvre, Cécile Bourreau-Dubois, Marc Ferracci, Roberto Galbiati and Samuel Ferey for their insightful comments, participants at the seminars in CRED-Paris II, ERUDITE-Paris Est, BETA-Lorraine University and Columbia University, as well as participants to the 3rd International Workshop on Economic Analysis of Litigation, the 32nd Conference of the Journées de Microéconomie Appliquée, the 64th annual Conference of the Association Française de Science Économique, and the 31st annual conference of the European Association of Law and Economics. We are also grateful to two anonymous referees, whose comments greatly contributed to the final version of this work. 


\section{References}

Anwar, S., Bayer, P., and Hjalmarsson, R. (2012). The impact of jury race in criminal trials. The Quarterly Journal of Economics, First published on-line.

Bafumi, J., Gelman, A., Park, D. K., and Kaplan, N. (2005). Practical issues in implementing and understanding bayesian ideal point estimation. Political Analysis, 3:171-197.

Berlemann, M. and Christman, R. (2016). Determinants of in-court settlement: Evidence from a german trial court. Working Paper.

Boyd, C. L., Epstein, L., and Martin, A. D. (2010). Untangling the causal effects of sex on judging. American Journal of Political Science, 54(2):389-411.

Brace, P. and Hall, M. G. (1995). Studying courts comparatively: The view from the american states. Political Research Quarterly, 48(1):5-29.

Brace, P., Yates, J., and Boyea, B. D. (2012). Judges, litigants, and the design of courts. Law \& Society Review, 46(3):497-522.

Brace, P. R. and Hall, M. G. (1997). The interplay of preferences, case facts, context, and rules in the politics of judicial choice. The Journal of Politics, 59(4):1206-1231.

Clermont, K. and Eisenberg, T. (2002). Plaintiphobia in the appellate courts: Civil rights really do differ from negotiable instruments? University of Illinois Law Review.

Cooter, R. and Ulen, T. (2016). Law and Economics, 6th edition. Berkeley Law Books.

Daughety, A. F. and Reinganum, J. F. (2012). Settlement. In Procedural Law and Economics. Edward Elgar Publishing.

De Maillard Taillefer, L. and Timbart, O. (2009). Les affaires prud'homales en 2007. Technical Report 105, Infostat, Ministère de la Justice.

Desrieux, C. and Espinosa, R. (2017). Enjeux et perspective de l'analyse économique des conseils de prud'hommes. Revue française d'économie, 1:137-168.

Eisenberg, T. (1991). The relationship between plaintiff success rates before trial and at trial. Journal of the Royal Statistical Society. Series A (Statistics in Society), 154(1):111-116.

Eisenberg, T. (1994). Negotiation, lawyering, and adjudication: Kritzer on brokers and deals. Law \& Social Inquiry, 19(1):275-299.

Eisenberg, T. and Farber, H. S. (1997). The Litigious Plaintiff Hypothesis: Case Selection and Resolution. Rand Journal of Economics, 28.

Eisenberg, T. and Lanvers, C. (2009). What is the settlemen rate and why should we care? Journal of Empirical Legal Studies, 6:111-146.

Epstein, L. and Kobylka, J. (1994). The Supreme Court and Legal Change: Abortion and the death Penalty. University of North Carolina Press.

Epstein, L., Landes, W. M., and Posner, R. A. (2013). The Behavior of Federal Judges: a theoretical and empirical study of rational choice. Harvard University Press. 
Epstein, L. and Lindquist, S. (2016). The Oxford Handbook of U.S. Judicial Behavior. Oxford University Press.

Espinosa, R. (2017). Constitutional Judicial Behavior: Exploring the Determinants of the Decisions of the French Constitutional Council. Review of Law and Economics, 13(2).

Espinosa, R., Desrieux, C., and Ferracci, M. (2017a). Labor Market and Access to Justice. International Review of Law and Economics (first on-line publication).

Espinosa, R., Desrieux, C., and Wan, H. (2017b). Fewer Courts, less justice? Evidence from the 2008 French Reform of labour Courts. European Journal of Law and Economics, 43(2):195-237.

Farhang, S. and Wawro, G. (2004). Institutional dynamics on the u.s. court of appeals: Minority representation under panel decision making. Journal of Law, Economics, and Organization, 20(2):299-330.

Fraisse, H., Kramarz, F., and Prost, C. (2014). Labor disputes and labor flows. Industrial Labor Relations Review, forthcoming.

Garoupa, N., Gomez-Pomer, F., and Grembi, V. (2011). Judging under political pressure: An empirical analysis of constitutional review voting in the spanish constitutional court. Journal of Law, Economics and Organization.

Glynn, A. N. and Sen, M. (2015). Identifying judicial empathy: Does having daughters cause judges to rule for women's issues? American Journal of Political Science, 59(1):37-54.

Gross, S. and Syveryd, K. (1991). Getting to no: A study of settlement negotiations and the selection of cases for trial. Michigan Law Review, 90:319-393.

Guillonneau, M. and Serverin, E. (2015). Les litiges individuels du travail de 2004 à 2013: des actions moins nombreuses mais toujours plus contentieuses. Technical Report 135, Infostat, Ministère de la Justice.

Hall, M. G. (1987). Constituent influence in state supreme courts: Conceptual notes and a case study. The Journal of Politics, 49(4):1117-1124.

Hall, M. G. (1992). Electoral politics and strategic voting in state supreme courts. The Journal of Politics, 54(2):427-446.

Hay, B. and Spier, K. (1998). Settlement of Litigation. In The New Palgrave Dictionary of Economics and the Law, number 442. MacMillan Reference Limited.

Hitt, M. P. (2013). Presidential success in supreme court appointments: Informational effects and institutional constraints. Presidential Studies Quarterly, 43(4):792-813.

Huang, K. (2008). How legal representation affects case outcomes: An empirical perspective from taiwan. Journal of Empirical Legal Studies, 5.

Huang, K.-C., Chen, K.-P., and Lin, C.-C. (2010). An empirical investigation of settlement and litigation: The case of taiwanese labor disputes. Journal of Empirical Legal Studies, 7(4):786-810.

Ichino, A., Polo, M., and Rettore, E. (2003). Are judges biased by labor market conditions? European Economic Review, 47(5):913-944. 
Kaplan, D., Sadka, J., and Silva-Mendez, J. L. (2008). Litigation and settlement: New evidence from labor courts in mexico. Journal of Empirical Legal Studies, 5(2):309-350.

Kessler, D., Meites, T., and Miller, G. P. (1996). Explaining Deviations from the Fifty-Percent Rule: A Multimodal Approach to the Selection of Cases for Litigation. The Journal of Legal Studies, 25(1):233-59.

Klerman, D. (2012). The selection of 13th-century disputes for litigation. Journal of Empirical Legal Studies, 9(2):320-346.

Kulik, C., Perry, E. L., and Pepper, M. B. (2003). Here comes the judge: The influence of judge personal characteristics on federal sexual harassment case outcomes. Law and Human Behavior, 27(1):69-86.

Lederman, L. (1999). Which cases go to trial: An empirical analysis of predictors of failure to settle. Case Western Reserve Law Review, 49(2):315-358.

Lim, C. S. (2013). Preferences and Incentives of Appointed and Elected Public Officials. American Economic Review, 103.

Loewenstein, G., I. S. C. C. and Babcock, L. (1993). Self-serving assessments of fairness and pretrial bargaining. The Journal of Legal Studies, 22(1):135 - 159.

Marinescu, I. (2011). Are judges sensitive to economic conditions? evidence from uk employment tribunals. Industrial and Labor Relations Review, 64(4):673-698.

Martin, A. D. and Quinn, K. M. (2002). Dynamic ideal point estimation via markov chain monte carlo for the u.s. supreme court, 1953-1999. Political Analysis, 10:134-153.

Martin, A. D., Quinn, K. M., and Epstein, L. (2005). The median justice on the united states supreme court. North Carolina Law Review, 5:1275-1320.

Peresie, J. (2005). Female judges matter: Gender and collegial decision making in the federal appellate courts. The Yale Law Journal, 114(7).

Perry, H. (1994). Deciding to Decide: Agenda Setting in the United States Supreme Court. Harvard University Press.

Priest, G. L. and Klein, B. (1984). The selection of disputes for litigation. The Journal of Legal $\underline{\text { Studies, }}$ 13(1):1-55.

Pérez-Liñán, A., Ames, B., and Seligson, M. A. (2006). Strategy, careers, and judicial decisions: Lessons from the bolivian courts. The Journal of Politics, 68(2):284-295.

Segal, J. A. and Spaeth, H. J. (1993). The Supreme Court and the Attitudinal Model. Cambridge University Press.

Segal, J. A. and Spaeth, H. J. (1996). The influence of stare decisis on the votes of united states supreme court justices. American Journal of Political Science, 40(4):971-1003.

Serverin, E. and Valentin, J. (2009). Licenciement et recours aux prud'hommes, questions de mesure. In Gomel, B., Méda, D., and Serverin, E., editors, L'emploi en ruptures. Dalloz. 
Shayo, M. and Zussman, A. (2011). Judicial Ingroup Bias in the Shadow of Terrorism. The Quarterly Journal of Economics, 126(3):1447-1484.

Songer, D. R. and Lindquist, S. A. (1996). Not the whole story: The impact of justices' values on supreme court decision making. American Journal of Political Science, 40(4):1049-1063.

Waldfogel, J. (1995). The Selection Hypothesis and the Relationship between Trial and Plaintiff Victory. Journal of Political Economy, 103(2):229-60. 


\section{Appendix A: Tables}

Summary statistics for each election between 1997 and 2012 are presented in tables A1, A2, and A3.

Table A1: Summary Statistics of the share of seats obtained by each union at the 1997 elections.

\begin{tabular}{lcccc}
\hline \multirow{2}{*}{ Union } & \multicolumn{4}{c}{ Share of seats } \\
\cline { 2 - 5 } & Mean & St. Dev. & Min & Max \\
\hline CGT & 0.346 & 0.190 & 0 & 0.833 \\
CFDT & 0.322 & 0.157 & 0 & 1 \\
FO & 0.220 & 0.133 & 0 & 0.75 \\
CGC & 0.065 & 0.137 & 0 & 0.75 \\
CFTC & 0.031 & 0.076 & 0 & 0.5 \\
UNSA & 0.005 & 0.039 & 0 & 0.5 \\
CSL & 0.003 & 0.018 & 0 & 0.25 \\
GDIX & 0.001 & 0.0123 & 0 & 0.25 \\
DIV & 0.007 & 0.045 & 0 & 0.6 \\
\hline \hline
\end{tabular}

Table A2: Summary Statistics of the share of seats obtained by each union at the 2002 elections.

\begin{tabular}{lcccc}
\hline \hline \multirow{2}{*}{ Union } & \multicolumn{4}{c}{ Share of seats } \\
\cline { 2 - 5 } & Mean & St. Dev. & Min & Max \\
\hline CGT & 0.350 & 0.188 & 0 & 0.8 \\
CFDT & 0.319 & 0.151 & 0 & 1 \\
FO & 0.183 & 0.131 & 0 & 0.667 \\
CFE-CGC & 0.071 & 0.149 & 0 & 0.75 \\
CFTC & 0.049 & 0.093 & 0 & 0.5 \\
UNSA & 0.016 & 0.058 & 0 & 0.5 \\
GSEA & 0.000 & 0.002 & 0 & 0.07 \\
GDIX & 0.003 & 0.028 & 0 & 0.5 \\
DIV & 0.007 & 0.052 & 0 & 0.75 \\
\hline \hline
\end{tabular}


Table A3: Summary Statistics of the share of seats obtained by each union at the 2008 elections.

\begin{tabular}{lcccc}
\hline \hline \multirow{2}{*}{ Union } & \multicolumn{4}{c}{ Share of seats } \\
\cline { 2 - 5 } & Mean & St. Dev. & Min & Max \\
\hline CGT & 0.397 & 0.189 & 0 & 1 \\
CFDT & 0.269 & 0.143 & 0 & 1 \\
FO & 0.160 & 0.113 & 0 & 0.667 \\
CFE-CGC & 0.089 & 0.172 & 0 & 0.75 \\
CFTC & 0.036 & 0.0814 & 0 & 1 \\
UNSA & 0.026 & 0.067 & 0 & 0.5 \\
Solidaires & 0.004 & 0.020 & 0 & 0.2 \\
DIV & 0.019 & 0.105 & 0 & 1 \\
\hline \hline
\end{tabular}


Table A4: Description of the variables.

\begin{tabular}{|c|c|}
\hline Variable Name & Description \\
\hline Conciliation & Dummy variable equal to 1 if the case is conciliated, 0 otherwise. \\
\hline Withdraw & $\begin{array}{l}\text { Dummy variable equal to } 1 \text { if the case is withdrawn, } 0 \text { if the case goes to full hearing, missing if } \\
\text { the case was settled at the conciliation stage. }\end{array}$ \\
\hline Decision 2 & $\begin{array}{l}\text { Dummy variable equal to } 1 \text { if the elected judges litigate the case in favor of the plaintiff, } 0 \text { if } \\
\text { litigated in his/her disfavor, missing if the case did not reach full hearing or if the elected judges } \\
\text { can't reach a decision. }\end{array}$ \\
\hline Referral & $\begin{array}{l}\text { Dummy variable equal to } 1 \text { a professional judge steps in, } 0 \text { if the elected judges decide the case } \\
\text { on their own, missing if the case did not reach full hearing. }\end{array}$ \\
\hline Judgement & $\begin{array}{l}\text { Dummy variable equal to } 1 \text { if the professional judge litigates the case in favor of the plaintiff, } 0 \\
\text { if litigated in his/her disfavor, missing if the case did not reach full hearing. }\end{array}$ \\
\hline Decision3 & $\begin{array}{l}\text { Variable equal to } 2 \text { if the elected judges litigate the case in favor of the plaintiff, } 0 \text { if litigated in } \\
\text { his/her disfavor, } 1 \text { if the elected judges can't reach a decision, missing if the case did not reach } \\
\text { full hearing. }\end{array}$ \\
\hline propConfront & Proportion of seats allocated to the CGT and FO at the court's section level. \\
\hline confront & Level of confrontation of the employees' representative at the court's section level. \\
\hline tv_contront & Level of time-varying confrontation of the employees' representative at the court's section level. \\
\hline shäreLeft & Share of votes of the first round of the presidential elections devoted to left-wing parties. \\
\hline avDurraffLY & $\begin{array}{l}\text { Average duration of cases terminated the previous year in the same section of the same court (in } \\
\text { days). }\end{array}$ \\
\hline unemployment & Unemployment rate at the department's level. \\
\hline $\operatorname{lngdp}$ & Logarithm of the GDP per capita at the regional level. \\
\hline woman & Dummy variable equal to 1 if the plaintiff is a female, al \\
\hline def_lawyer & Dummy variable equal to 1 if the defendant is represented by a lawyer, 0 otherwise. \\
\hline def_unionWorker & Dummy variable equal to 1 if the defendant is represented by a worker unionist, 0 otherwise. \\
\hline def_unionEmployer & Dummy variable equal to 1 if the defendant is represented by a employer unionist, 0 otherwise. \\
\hline plaint_lawyer & Dummy variable equal to 1 if the plaintiff is represented by a lawyer, 0 otherwise. \\
\hline plaint_union & Dummy variable equal to 1 if the plaintiff is represented by a worker unionist, 0 otherwise. \\
\hline
\end{tabular}


Table A5: Descriptive statistics at each decision step (corresponding to the regression samples of table 2).

\begin{tabular}{|c|c|c|c|c|c|}
\hline Variable & Conciliation & Withdraw & $\overline{\text { Decision2 }}$ & Referral & Judgement \\
\hline Conciliation & $\begin{array}{l}.135 \\
(.3417)\end{array}$ & & & & \\
\hline Withdraw & .278 & $(.448)$ & & & \\
\hline Decision2 & & & $\begin{array}{l}.7315 \\
(.4432)\end{array}$ & & \\
\hline Referral & & & & $\begin{array}{l}.162 \\
(.3685)\end{array}$ & \\
\hline Judgement & & & & & $\begin{array}{c}.6988 \\
(.4588)\end{array}$ \\
\hline propConfront & $\begin{array}{c}.5205 \\
(.2167)\end{array}$ & $\begin{array}{l}.5203 \\
(.2133)\end{array}$ & $\begin{array}{c}.5192 \\
(.2161)\end{array}$ & $\begin{array}{c}.5189 \\
(.2141)\end{array}$ & $\begin{array}{l}.5128 \\
(.207)\end{array}$ \\
\hline confront & $\begin{array}{c}.7878 \\
(1.0708)\end{array}$ & $\begin{array}{c}0.8177 \\
(1.061)\end{array}$ & $\begin{array}{c}0.7990 \\
(1.068)\end{array}$ & $\begin{array}{l}0.8096 \\
(1.061)\end{array}$ & $\begin{array}{l}0.8391 \\
(1.034)\end{array}$ \\
\hline tv_confront & $\begin{array}{l}-1.0634 \\
(1.0151)\end{array}$ & $\begin{array}{r}-1.1246 \\
(1.008)\end{array}$ & $\begin{array}{r}-1.1187 \\
(1.014)\end{array}$ & $\begin{array}{l}-1.123 \\
(1.007)\end{array}$ & $\begin{array}{l}-1.173 \\
(.9855)\end{array}$ \\
\hline shareLeft & $\begin{array}{l}.4289 \\
(.0636)\end{array}$ & $\begin{array}{l}.4285 \\
(.0648)\end{array}$ & $\begin{array}{c}.4279 \\
(.0643)\end{array}$ & $\begin{array}{c}.4288 \\
(.0642)\end{array}$ & $\begin{array}{c}.4331 \\
(.0636)\end{array}$ \\
\hline avDurraffLY & $\begin{array}{c}396.183 \\
(127.9133)\end{array}$ & $\begin{array}{c}412.0879 \\
(134.6883)\end{array}$ & $\begin{array}{l}403.1429 \\
(130.755)\end{array}$ & $\begin{array}{c}410.3286 \\
(134.7873)\end{array}$ & $\begin{array}{c}442.7418 \\
(148.263)\end{array}$ \\
\hline unemployment & $\begin{array}{c}8.2339 \\
(2.0714)\end{array}$ & $\begin{array}{c}8.1177 \\
(1.8837)\end{array}$ & $\begin{array}{l}8.1434 \\
(1.869)\end{array}$ & $\begin{array}{l}8.1262 \\
(1.87)\end{array}$ & $\begin{array}{c}8.057 \\
(1.885)\end{array}$ \\
\hline $\operatorname{lngdp}$ & $\begin{array}{l}10.2258 \\
(.2867)\end{array}$ & $\begin{array}{l}10.2571 \\
(.2946)\end{array}$ & $\begin{array}{l}10.2387 \\
(.2893)\end{array}$ & $\begin{array}{l}10.2506 \\
(.2918)\end{array}$ & $\begin{array}{l}10.3084 \\
(.2984)\end{array}$ \\
\hline woman & $\begin{array}{l}.3842 \\
(.4864)\end{array}$ & $\begin{array}{c}.3788 \\
(.4851)\end{array}$ & $\begin{array}{c}.376 \\
(.4844)\end{array}$ & $\begin{array}{l}.3811 \\
(.4857)\end{array}$ & $\begin{array}{c}.405 \\
(.4909)\end{array}$ \\
\hline def_lawyer & $\begin{array}{c}.2074 \\
(.4055)\end{array}$ & $\begin{array}{l}.2139 \\
(.41)\end{array}$ & $\begin{array}{c}.2391 \\
(.4265)\end{array}$ & $\begin{array}{c}.2279 \\
(.4195)\end{array}$ & $\begin{array}{c}.1743 \\
(.3793)\end{array}$ \\
\hline def_unionWorker & $\begin{array}{c}.0004 \\
(.0206)\end{array}$ & $\begin{array}{c}.0004 \\
(.0203)\end{array}$ & $\begin{array}{c}.0005 \\
(.0214)\end{array}$ & $\begin{array}{c}.0004 \\
(.0206)\end{array}$ & $\begin{array}{c}.0003 \\
(.0172)\end{array}$ \\
\hline def_unionEmployer & $\begin{array}{c}.0017 \\
(.0415)\end{array}$ & $\begin{array}{c}.0014 \\
(.0373)\end{array}$ & $\begin{array}{l}.0016 \\
(.0405)\end{array}$ & $\begin{array}{l}.0015 \\
(.0392)\end{array}$ & $\begin{array}{c}.0011 \\
(.0324)\end{array}$ \\
\hline plaint_lawyer & $\begin{array}{c}.1917 \\
(.3937)\end{array}$ & $\begin{array}{l}.1946 \\
(.3959)\end{array}$ & $\begin{array}{l}.2097 \\
(.4071)\end{array}$ & $\begin{array}{l}.2043 \\
(.4032)\end{array}$ & $\begin{array}{c}.1799 \\
(.3841)\end{array}$ \\
\hline plaint_unionWorker & $\begin{array}{c}.0718 \\
(.2582)\end{array}$ & $\begin{array}{c}.0677 \\
(.2512)\end{array}$ & $\begin{array}{l}.0758 \\
(.2647)\end{array}$ & $\begin{array}{c}.0718 \\
(.2581)\end{array}$ & $\begin{array}{c}.0541 \\
(.2262)\end{array}$ \\
\hline
\end{tabular}

Means. Standard deviations in parentheses. 


\section{Appendix B. Bayesian Estimation of Ideal Points}

The Bayesian estimation of ideal points is usually referred as the one dimensional item response theory. Such models originally aimed at measuring students' performance to a test, and to locate them on a unique dimension. The objective consisted in estimating three sets of parameters: $(i)$ an ability parameter for each student, (ii) a difficulty parameter for each question of the test, and (iii) a discrimination parameter for each question. Bayesian methods were developed to discriminate students according to their ability, by taking into account questions' difficulty level, and by estimating their 'relevance' to correctly discriminate students. ${ }^{35}$

These models have then be used in the political science literature, especially in the case of Supreme Court voting (Bafumi et al. (2005), Martin and Quinn (2002), Martin et al. (2005)), where researchers were willing to locate Justices on a liberal-conservative dimension. Our approach follows this literature: we aim at locating unions on a confrontation propensity axis by investigating their ability to successfully negotiate with firms owners.

More formally, our goal consists in estimating unions' positions $\left(\beta_{i}\right)$ on a confrontation propensity axis. To do so, as explained in footnote 18, we use a database on past inter-professional national agreements (ANI). They are country-wide agreements between worker unions and firm owners' representatives that each union can decide to sign or not. We estimate ANI-specific parameters, i.e. their location on the confrontation axis $\left(\alpha_{j}\right)$ and their discrimination parameter $\left(\gamma_{j}\right)$, i.e. their capacity to discriminate unions on the confrontation dimension. The model is defined by a logistic utility model, where the latent utility depends both on unions and ANI parameters:

$$
u_{i, j}=-\alpha_{j}+\gamma_{j} \beta_{i}+\epsilon_{i, j}
$$

where $u_{i, j}$ is the utility of union $i$ to ratify ANI $j$, and $\epsilon_{i, j}$ is a random component.

Ideal points are assumed to be normally distributed with mean $\mu_{\beta}$ and variance $\sigma_{\beta}^{2}$, and the ANI-specific parameters are assumed to be jointly distributed : $\left(\alpha_{j}, \gamma_{j}\right) \sim N_{2}\left(M, T^{-1}\right)$. In order to avoid additive and multiplicative aliasing, as well as reflection invariance, we set parameters' priors to default values of the MCMCpackage in $\mathrm{R}\left(\mu_{\beta}=0, \sigma_{\beta}=1, M=0\right.$, and $\left.T=0.25\right)$. Moreover, identification requires an additional constraint on the ideal points. Since our goal is to create a confrontational scale, we assume that the CGT, which is usually seen as the least likely to negotiate with firm owners, is more confrontational than the CFDT, which is seen as the most confrontational union. In other words, we constraint the model such that the CGT will get a positive score on the confrontational dimension, while the CFDT will get a negative score on the confrontational dimension. Of course, such a constraint does not claim that the CFDT is not confrontational at all, it only assumes that the CGT is more confrontational than the CFDT.

The first Bayesian estimate yields the results presented in figure B4. These results are in line with the classical distinction between confrontational unions (CGT and FO) and the others (CFDT, CGC, CFTC). It reveals however a strong heterogeneity among the two most confrontational unions, which reflects the limits of the first measure (propConfront). Indeed, the two most confrontational unions (FO and CGT) have different intensities of opposition to reforms. We use the results of this estimation to compute the second proxy for courts' preferences for confrontation (confront).

The second Bayesian estimate ( $t v_{-}$confront) allows for time-varying preferences. The results of this estimation are given in figure B5. They give a similar picture to the first Bayesian estimation

\footnotetext{
${ }^{35}$ Researchers anticipated the possibility that some questions could be correctly answered by low-skilled students and wrongly answered by high-skilled students
} 
Figure B4: Results of the Bayesian estimation of unions' ideal points.

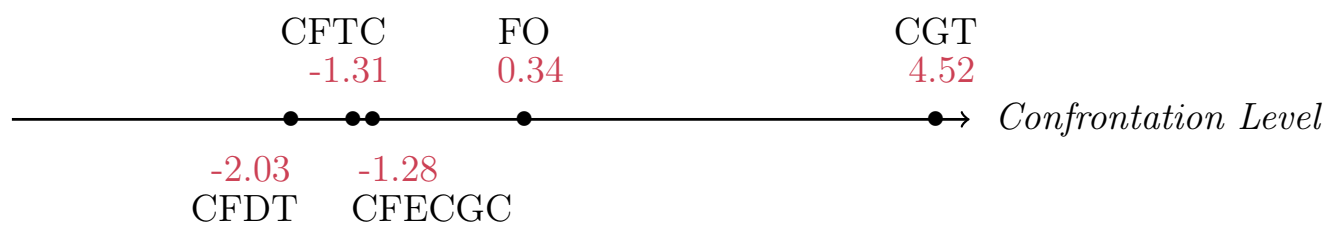

but shows that the ideological gap between the two most confrontational unions has varied over time. We use the results of this estimation to compute the last measure of courts' preferences for confrontation ( $t v_{-}$confront).

Figure B5: Results of the Bayesian estimation of time varying unions' ideal points.

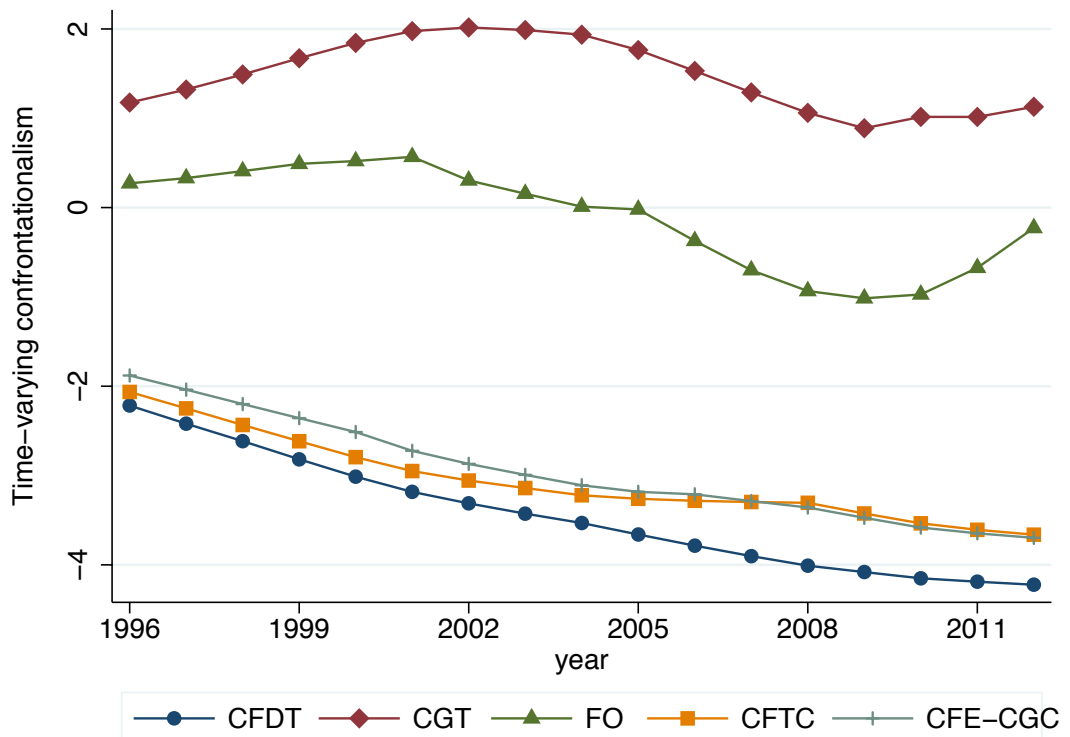




\section{Online Appendix}

\section{Online Appendix A: BASELINe Tables}

We display the full set of estimates of the main regressions of the paper. Tables Online-A1, Online-A2 and Online-A3 show the estimates for the baseline model for propConfront, confront and $t v_{-}$confront respectively. 
Table Online-A1: Results of probit and ordered probit estimation of the set of dependent variables. Court's composition: propConfront. Baseline Model.

\begin{tabular}{|c|c|c|c|c|c|c|}
\hline $\begin{array}{l}\text { Variable } \\
\text { Technique }\end{array}$ & $\begin{array}{c}\text { Conciliation } \\
\text { Probit }\end{array}$ & $\begin{array}{c}\text { Withdraw } \\
\text { Probit }\end{array}$ & $\begin{array}{c}\text { Decision3 } \\
\text { Ordered Pr. }\end{array}$ & $\begin{array}{c}\text { Decision2 } \\
\text { Probit }\end{array}$ & $\begin{array}{c}\text { Referral } \\
\text { Probit }\end{array}$ & $\begin{array}{c}\text { Judgement } \\
\text { Probit } \\
\end{array}$ \\
\hline propConfront & $\begin{array}{c}0.0502^{* * *} \\
(2.861)\end{array}$ & $\begin{array}{c}0.364^{* * *} \\
(23.00)\end{array}$ & $\begin{array}{c}-0.0358^{* *} \\
(-2.056)\end{array}$ & $\begin{array}{l}-0.0216 \\
(-1.042)\end{array}$ & $\begin{array}{c}0.0898^{* * *} \\
(4.020)\end{array}$ & $\begin{array}{l}0.0102 \\
(0.186)\end{array}$ \\
\hline shareLeft & $\begin{array}{c}1.150^{* * *} \\
(8.018)\end{array}$ & $\begin{array}{c}-0.452^{* * *} \\
(-3.826)\end{array}$ & $\begin{array}{l}0.0176 \\
(0.140)\end{array}$ & $\begin{array}{l}0.274^{*} \\
(1.820)\end{array}$ & $\begin{array}{c}1.599^{* * *} \\
(9.951)\end{array}$ & $\begin{array}{c}1.806^{* * * *} \\
(4.567)\end{array}$ \\
\hline avDuraffLY & $\begin{array}{c}4.04 \mathrm{e}-05^{* *} \\
(2.015)\end{array}$ & $\begin{array}{c}-0.000299^{* * *} \\
(-17.36)\end{array}$ & & & & \\
\hline unemployment & $\begin{array}{c}0.00110 \\
(1.378)\end{array}$ & $\begin{array}{c}-0.00673^{* * *} \\
(-7.402)\end{array}$ & $\begin{array}{c}-0.00605^{* * *} \\
(-6.627)\end{array}$ & $\begin{array}{c}-0.00367^{* * * *} \\
(-3.320)\end{array}$ & $\begin{array}{c}0.0141^{* * *} \\
(11.95)\end{array}$ & $\begin{array}{c}0.0186^{* * *} \\
(6.820)\end{array}$ \\
\hline $\operatorname{lngdppc}$ & $\begin{array}{c}0.542^{* * *} \\
(8.182)\end{array}$ & $\begin{array}{c}-0.157^{* * *} \\
(-2.687)\end{array}$ & $\begin{array}{c}-0.368^{* * *} \\
(-5.796)\end{array}$ & $\begin{array}{c}-0.463^{* * *} \\
(-6.121)\end{array}$ & $\begin{array}{l}0.00679 \\
(0.0824)\end{array}$ & $\begin{array}{c}-1.721^{* * *} \\
(-8.768)\end{array}$ \\
\hline gender & $\begin{array}{c}0.0635^{* * *} \\
(21.46)\end{array}$ & $\begin{array}{c}-0.0296^{* * *} \\
(-10.94)\end{array}$ & $\begin{array}{c}0.0413^{* * * *} \\
(14.45)\end{array}$ & $\begin{array}{c}0.0646^{* * *} \\
(18.35)\end{array}$ & $\begin{array}{c}0.0449^{* * *} \\
(12.22)\end{array}$ & $\begin{array}{c}0.0470^{* * *} \\
(5.727)\end{array}$ \\
\hline def_lawyer & $\begin{array}{c}-0.256^{* * *} \\
(-51.36)\end{array}$ & $\begin{array}{c}-0.155^{* * *} \\
(-34.79)\end{array}$ & $\begin{array}{c}0.0717^{* * * *} \\
(15.40)\end{array}$ & $\begin{array}{c}0.0618^{* * *} \\
(11.58)\end{array}$ & $\begin{array}{c}-0.113^{* * *} \\
(-19.54)\end{array}$ & $\begin{array}{c}-0.150^{* * *} \\
(-9.231)\end{array}$ \\
\hline def_workerUnion & $\begin{array}{l}-0.0287 \\
(-0.435)\end{array}$ & $\begin{array}{c}-0.194^{* * *} \\
(-3.140)\end{array}$ & $\begin{array}{l}-0.0243 \\
(-0.344)\end{array}$ & $\begin{array}{l}-0.0404 \\
(-0.520)\end{array}$ & $\begin{array}{l}-0.0620 \\
(-0.646)\end{array}$ & $\begin{array}{c}-0.648^{* * *} \\
(-3.073)\end{array}$ \\
\hline def_employerUnion & $\begin{array}{c}0.432^{* * *} \\
(15.07)\end{array}$ & $\begin{array}{c}-0.255^{* * *} \\
(-6.927)\end{array}$ & $\begin{array}{c}-0.171^{* * *} \\
(-4.740)\end{array}$ & $\begin{array}{c}-0.228^{* * *} \\
(-5.826)\end{array}$ & $\begin{array}{c}-0.229^{* * *} \\
(-4.520)\end{array}$ & $\begin{array}{l}-0.109 \\
(-0.847)\end{array}$ \\
\hline plaint_lawyer & $\begin{array}{c}0.108^{* * *} \\
(18.00)\end{array}$ & $\begin{array}{c}-0.142^{* * *} \\
(-23.22)\end{array}$ & $\begin{array}{c}0.0135^{*} \\
(1.815)\end{array}$ & $\begin{array}{c}0.0346^{* * *} \\
(4.263)\end{array}$ & $\begin{array}{c}0.0839^{* * *} \\
(9.999)\end{array}$ & $\begin{array}{c}0.0963^{* * *} \\
(3.124)\end{array}$ \\
\hline plaint_union & $\begin{array}{c}0.278^{* * * *} \\
(38.32)\end{array}$ & $\begin{array}{c}-0.191^{* * *} \\
(-25.05)\end{array}$ & $\begin{array}{c}-0.0438^{* * *} \\
(-4.917)\end{array}$ & $\begin{array}{c}-0.0234^{* *} \\
(-2.387)\end{array}$ & $\begin{array}{c}0.116^{* * *} \\
(10.71)\end{array}$ & $\begin{array}{c}-0.0857^{* *} \\
(-2.478)\end{array}$ \\
\hline$($ court $\times$ Section $) \mathrm{FE}$ & Yes & Yes & Yes & Yes & Yes & Yes \\
\hline Year FE & Yes & Yes & Yes & Yes & Yes & Yes \\
\hline $\begin{array}{l}\text { Observations } \\
\text { LL } \\
\text { Pseudo-R2 }\end{array}$ & $\begin{array}{c}1,343,494 \\
-503238 \\
0.0536\end{array}$ & $\begin{array}{c}1,160,938 \\
-666878 \\
0.0282\end{array}$ & $\begin{array}{c}838,895 \\
-765264 \\
0.0189\end{array}$ & $\begin{array}{c}703,455 \\
-396841 \\
0.0302\end{array}$ & $\begin{array}{c}840,020 \\
-338718 \\
0.0898\end{array}$ & $\begin{array}{c}125,613 \\
-71253 \\
0.0728\end{array}$ \\
\hline
\end{tabular}

Significance level: ${ }^{* * *}$ significant at $1 \%$ level ${ }^{* *}$ significant at $5 \%$ level $*$ significant at $10 \%$ level.

Robust z-statistics in parentheses. 
Table Online-A2: Results of probit and ordered probit estimation of the set of dependent variables. Court's composition: confront. Baseline Model.

\begin{tabular}{|c|c|c|c|c|c|c|}
\hline $\begin{array}{l}\text { Variable } \\
\text { Technique }\end{array}$ & $\begin{array}{c}\text { Conciliation } \\
\text { Probit }\end{array}$ & $\begin{array}{c}\text { Withdraw } \\
\text { Probit }\end{array}$ & $\begin{array}{c}\text { Decision3 } \\
\text { Ordered Pr. }\end{array}$ & $\begin{array}{c}\text { Decision2 } \\
\text { Probit }\end{array}$ & $\begin{array}{c}\text { Referral } \\
\text { Probit }\end{array}$ & $\begin{array}{c}\text { Judgement } \\
\text { Probit }\end{array}$ \\
\hline confront & $\begin{array}{c}0.00565^{*} \\
(1.731)\end{array}$ & $\begin{array}{c}0.0604^{* * *} \\
(20.39)\end{array}$ & $\begin{array}{c}0.00242 \\
(0.745)\end{array}$ & $\begin{array}{c}0.00611 \\
(1.592)\end{array}$ & $\begin{array}{c}0.0104^{* *} \\
(2.492)\end{array}$ & $\begin{array}{c}0.00239 \\
(0.233)\end{array}$ \\
\hline shareLeft & $\begin{array}{c}1.136^{* * *} \\
(7.918)\end{array}$ & $\begin{array}{c}-0.478^{* * *} \\
(-4.041)\end{array}$ & $\begin{array}{l}0.0518 \\
(0.411)\end{array}$ & $\begin{array}{c}0.315^{* *} \\
(2.091)\end{array}$ & $\begin{array}{c}1.582^{* * *} \\
(9.836)\end{array}$ & $\begin{array}{c}1.808^{* * *} \\
(4.570)\end{array}$ \\
\hline avDuraffLY & $\begin{array}{c}4.01 \mathrm{e}-05^{* *} \\
(2.000)\end{array}$ & $\begin{array}{c}-0.000298^{* * *} \\
(-17.27)\end{array}$ & & & & \\
\hline unemployment & $\begin{array}{c}0.00109 \\
(1.372)\end{array}$ & $\begin{array}{c}-0.00690^{* * *} \\
(-7.596)\end{array}$ & $\begin{array}{c}-0.00606^{* * *} \\
(-6.638)\end{array}$ & $\begin{array}{c}-0.00370^{* * *} \\
(-3.347)\end{array}$ & $\begin{array}{c}0.0141^{* * *} \\
(11.97)\end{array}$ & $\begin{array}{c}0.0186^{* * *} \\
(6.821)\end{array}$ \\
\hline $\operatorname{lngdppc}$ & $\begin{array}{c}0.535^{* * *} \\
(8.078)\end{array}$ & $\begin{array}{c}-0.187^{* * *} \\
(-3.211)\end{array}$ & $\begin{array}{c}-0.354^{* * *} \\
(-5.582)\end{array}$ & $\begin{array}{c}-0.448^{* * *} \\
(-5.932)\end{array}$ & $\begin{array}{l}-0.00684 \\
(-0.0830)\end{array}$ & $\begin{array}{c}-1.720^{* * *} \\
(-8.765)\end{array}$ \\
\hline gender & $\begin{array}{c}0.0635^{* * * *} \\
(21.46)\end{array}$ & $\begin{array}{c}-0.0296^{* * *} \\
(-10.94)\end{array}$ & $\begin{array}{c}0.0413^{* * * *} \\
(14.46)\end{array}$ & $\begin{array}{c}0.0646^{* * *} \\
(18.35)\end{array}$ & $\begin{array}{c}0.0448^{* * *} \\
(12.22)\end{array}$ & $\begin{array}{c}0.0470^{* * * *} \\
(5.725)\end{array}$ \\
\hline def_lawyer & $\begin{array}{c}-0.257^{* * *} \\
(-51.38)\end{array}$ & $\begin{array}{c}-0.154^{* * *} \\
(-34.78)\end{array}$ & $\begin{array}{c}0.0715^{* * * *} \\
(15.37)\end{array}$ & $\begin{array}{c}0.0617^{* * *} \\
(11.57)\end{array}$ & $\begin{array}{c}-0.113^{* * *} \\
(-19.51)\end{array}$ & $\begin{array}{c}-0.150^{* * * *} \\
(-9.232)\end{array}$ \\
\hline def_workerUnion & $\begin{array}{l}-0.0286 \\
(-0.434)\end{array}$ & $\begin{array}{c}-0.197^{* * *} \\
(-3.182)\end{array}$ & $\begin{array}{l}-0.0255 \\
(-0.361)\end{array}$ & $\begin{array}{l}-0.0417 \\
(-0.536)\end{array}$ & $\begin{array}{l}-0.0616 \\
(-0.642)\end{array}$ & $\begin{array}{c}-0.648^{* * *} \\
(-3.074)\end{array}$ \\
\hline def_employerUnion & $\begin{array}{c}0.432^{* * *} \\
(15.06)\end{array}$ & $\begin{array}{c}-0.255^{* * *} \\
(-6.941)\end{array}$ & $\begin{array}{c}-0.170 * * * \\
(-4.728)\end{array}$ & $\begin{array}{c}-0.228^{* * *} \\
(-5.814)\end{array}$ & $\begin{array}{c}-0.229^{* * *} \\
(-4.526)\end{array}$ & $\begin{array}{l}-0.109 \\
(-0.846)\end{array}$ \\
\hline plaint_lawyer & $\begin{array}{c}0.108^{* * *} \\
(17.99)\end{array}$ & $\begin{array}{c}-0.143^{* * *} \\
(-23.44)\end{array}$ & $\begin{array}{c}0.0135^{*} \\
(1.814)\end{array}$ & $\begin{array}{c}0.0346^{* * *} \\
(4.258)\end{array}$ & $\begin{array}{c}0.0839^{* * *} \\
(9.993)\end{array}$ & $\begin{array}{c}0.0963^{* * *} \\
(3.123)\end{array}$ \\
\hline plaint_union & $\begin{array}{c}0.278^{* * *} \\
(38.30)\end{array}$ & $\begin{array}{c}-0.193^{* * *} \\
(-25.27)\end{array}$ & $\begin{array}{c}-0.0437^{* * *} \\
(-4.909)\end{array}$ & $\begin{array}{c}-0.0233^{* *} \\
(-2.382)\end{array}$ & $\begin{array}{c}0.116^{* * *} \\
(10.70)\end{array}$ & $\begin{array}{c}-0.0857^{* *} \\
(-2.479)\end{array}$ \\
\hline$($ court $\times$ Section $) \mathrm{FE}$ & Yes & Yes & Yes & Yes & Yes & Yes \\
\hline Year FE & Yes & Yes & Yes & Yes & Yes & Yes \\
\hline Observations & $1,343,494$ & $1,160,938$ & 838,895 & 703,455 & 840,020 & 125,613 \\
\hline LL & -503241 & -666933 & -765266 & -396840 & -338723 & -71253 \\
\hline Pseudo-R2 & 0.0536 & 0.0281 & 0.0189 & 0.0302 & 0.0898 & 0.0728 \\
\hline
\end{tabular}


Table Online-A3: Results of probit and ordered probit estimation of the set of dependent variables. Court's composition: tv_confront. Baseline

\begin{tabular}{|c|c|c|c|c|c|c|}
\hline $\begin{array}{l}\text { Variable } \\
\text { Technique }\end{array}$ & $\begin{array}{c}\text { Conciliation } \\
\text { Probit }\end{array}$ & $\begin{array}{c}\text { Withdraw } \\
\text { Probit }\end{array}$ & $\begin{array}{c}\text { Decision3 } \\
\text { Ordered Pr. }\end{array}$ & $\begin{array}{c}\text { Decision2 } \\
\text { Probit } \\
\end{array}$ & $\begin{array}{c}\text { Referral } \\
\text { Probit }\end{array}$ & $\begin{array}{c}\text { Judgement } \\
\text { Probit }\end{array}$ \\
\hline tv_confront & $\begin{array}{c}0.00565^{*} \\
(1.731)\end{array}$ & $\begin{array}{c}0.0604^{* * *} \\
(20.39)\end{array}$ & $\begin{array}{c}0.00242 \\
(0.745)\end{array}$ & $\begin{array}{c}0.00611 \\
(1.592)\end{array}$ & $\begin{array}{c}0.0104^{* *} \\
(2.492)\end{array}$ & $\begin{array}{c}0.00239 \\
(0.233)\end{array}$ \\
\hline shareLeft & $\begin{array}{c}1.136^{* * *} \\
(7.918)\end{array}$ & $\begin{array}{c}-0.478^{* * *} \\
(-4.041)\end{array}$ & $\begin{array}{l}0.0518 \\
(0.411)\end{array}$ & $\begin{array}{c}0.315^{* *} \\
(2.091)\end{array}$ & $\begin{array}{c}1.582^{* * *} \\
(9.836)\end{array}$ & $\begin{array}{c}1.808^{* * *} \\
(4.570)\end{array}$ \\
\hline avDuraffLY & $\begin{array}{c}4.01 \mathrm{e}-05^{* *} \\
(2.000)\end{array}$ & $\begin{array}{c}-0.000298^{* * *} \\
(-17.27)\end{array}$ & & & & \\
\hline unemployment & $\begin{array}{c}0.00109 \\
(1.372)\end{array}$ & $\begin{array}{c}-0.00690^{* * *} \\
(-7.596)\end{array}$ & $\begin{array}{c}-0.00606^{* * *} \\
(-6.638)\end{array}$ & $\begin{array}{c}-0.00370^{* * *} \\
(-3.347)\end{array}$ & $\begin{array}{c}0.0141^{* * *} \\
(11.97)\end{array}$ & $\begin{array}{c}0.0186^{* * *} \\
(6.821)\end{array}$ \\
\hline $\operatorname{lngdppc}$ & $\begin{array}{c}0.535^{* * *} \\
(8.078)\end{array}$ & $\begin{array}{c}-0.187^{* * *} \\
(-3.211)\end{array}$ & $\begin{array}{c}-0.354^{* * *} \\
(-5.582)\end{array}$ & $\begin{array}{c}-0.448^{* * *} \\
(-5.932)\end{array}$ & $\begin{array}{l}-0.00684 \\
(-0.0830)\end{array}$ & $\begin{array}{c}-1.720^{* * *} \\
(-8.765)\end{array}$ \\
\hline gender & $\begin{array}{c}0.0635^{* * *} \\
(21.46)\end{array}$ & $\begin{array}{c}-0.0296^{* * *} \\
(-10.94)\end{array}$ & $\begin{array}{c}0.0413^{* * *} \\
(14.46)\end{array}$ & $\begin{array}{c}0.0646^{* * *} \\
(18.35)\end{array}$ & $\begin{array}{c}0.0448^{* * *} \\
(12.22)\end{array}$ & $\begin{array}{c}0.0470^{* * * *} \\
(5.725)\end{array}$ \\
\hline def_lawyer & $\begin{array}{c}-0.257^{* * *} \\
(-51.38)\end{array}$ & $\begin{array}{c}-0.154^{* * *} \\
(-34.78)\end{array}$ & $\begin{array}{c}0.0715^{* * *} \\
(15.37)\end{array}$ & $\begin{array}{c}0.0617^{* * *} \\
(11.57)\end{array}$ & $\begin{array}{c}-0.113^{* * *} \\
(-19.51)\end{array}$ & $\begin{array}{c}-0.150^{* * *} \\
(-9.232)\end{array}$ \\
\hline def_workerUnion & $\begin{array}{l}-0.0286 \\
(-0.434)\end{array}$ & $\begin{array}{c}-0.197^{* * *} \\
(-3.182)\end{array}$ & $\begin{array}{l}-0.0255 \\
(-0.361)\end{array}$ & $\begin{array}{l}-0.0417 \\
(-0.536)\end{array}$ & $\begin{array}{l}-0.0616 \\
(-0.642)\end{array}$ & $\begin{array}{c}-0.648^{* * *} \\
(-3.074)\end{array}$ \\
\hline def_employerUnion & $\begin{array}{c}0.432^{* * *} \\
(15.06)\end{array}$ & $\begin{array}{c}-0.255^{* * *} \\
(-6.941)\end{array}$ & $\begin{array}{c}-0.170^{* * *} \\
(-4.728)\end{array}$ & $\begin{array}{c}-0.228^{* * *} \\
(-5.814)\end{array}$ & $\begin{array}{c}-0.229 * * * \\
(-4.526)\end{array}$ & $\begin{array}{l}-0.109 \\
(-0.846)\end{array}$ \\
\hline plaint_lawyer & $\begin{array}{c}0.108^{* * *} \\
(17.99)\end{array}$ & $\begin{array}{c}-0.143^{* * *} \\
(-23.44)\end{array}$ & $\begin{array}{c}0.0135^{*} \\
(1.814)\end{array}$ & $\begin{array}{c}0.0346^{* * *} \\
(4.258)\end{array}$ & $\begin{array}{c}0.0839^{* * *} \\
(9.993)\end{array}$ & $\begin{array}{c}0.0963^{* * *} \\
(3.123)\end{array}$ \\
\hline plaint_union & $\begin{array}{c}0.278^{* * *} \\
(38.30)\end{array}$ & $\begin{array}{c}-0.193^{* * *} \\
(-25.27)\end{array}$ & $\begin{array}{c}-0.0437^{* * *} \\
(-4.909)\end{array}$ & $\begin{array}{c}-0.0233^{* *} \\
(-2.382)\end{array}$ & $\begin{array}{c}0.116^{* * *} \\
(10.70)\end{array}$ & $\begin{array}{c}-0.0857^{* *} \\
(-2.479)\end{array}$ \\
\hline$($ court $\times$ Section $) \mathrm{FE}$ & Yes & Yes & Yes & Yes & Yes & Yes \\
\hline Year FE & Yes & Yes & Yes & Yes & Yes & Yes \\
\hline Observations & $1,343,494$ & $1,160,938$ & 838,895 & 703,455 & 840,020 & 125,613 \\
\hline $\mathrm{LL}$ & -503241 & -666933 & -765266 & -396840 & -338723 & -71253 \\
\hline Pseudo-R2 & 0.0536 & 0.0281 & 0.0189 & 0.0302 & 0.0898 & 0.0728 \\
\hline
\end{tabular}

Significance level: $* * *$ significant at $1 \%$ level ${ }^{* *}$ significant at $5 \%$ level $*$ significant at $10 \%$ level.

Robust z-statistics in parentheses. 


\section{Online Appendix B: Triprobit}

The latent utilities of Conciliation, Withdraw and Decision2 are defined as follows:

$$
\begin{aligned}
y_{c i}^{*} & =X_{c i} \beta_{c}+u_{c i} \\
y_{w i}^{*} & =X_{w i} \beta_{w}+u_{w i} \\
y_{d i}^{*} & =X_{d i} \beta_{d}+u_{d i}
\end{aligned}
$$

The outcome of the Withdraw decision is not observed if the case is conciliated. The decision of the elected judges is not available if the case is conciliated or withdrawn. The system of observed outcomes is:

$$
\begin{aligned}
& y_{c i}= \begin{cases}0 & \text { if } y_{c i}^{*} \leq 0 \\
1 & \text { if } y_{c i}^{*}>0\end{cases} \\
& y_{w i}= \begin{cases}\cdot & \text { if } y_{c i}^{*}>0 \\
0 & \text { if } y_{w i}^{*} \leq 0 \text { and } y_{c i}^{*} \leq 0 \\
1 & \text { if } y_{w i}^{*}>0 \text { and } y_{c i}^{*} \leq 0\end{cases} \\
& y_{d i}= \begin{cases}\cdot & \text { if } y_{w i}^{*}>0 \text { or } y_{c i}^{*}>0 \\
0 & \text { if } y_{d i}^{*} \leq 0 \text { and } y_{w i}^{*} \leq 0 \text { and } y_{c i}^{*} \leq 0 \\
1 & \text { if } y_{d i}^{*}>0 \text { and } y_{w i}^{*} \leq 0 \text { and } y_{c i}^{*} \leq 0\end{cases}
\end{aligned}
$$

Assuming that the error terms are normally distributed, we compute the contributions to the likelihood. We note $\rho_{c w}, \rho_{c d}$ and $\rho_{w d}$ the correlations between $u_{c}$ and $u_{w}, u_{c}$ and $u_{d}, u_{w}$ and $u_{d}$. We note $V=\left[\begin{array}{ccc}1 & & \\ \rho_{c w} & 1 & \\ -\rho_{c d} & -\rho_{w d} & 1\end{array}\right]$ and $V^{\prime}=\left[\begin{array}{ccc}1 & & \\ \rho_{c w} & 1 & \\ \rho_{c d} & \rho_{w d} & 1\end{array}\right]$.

The contribution for a conciliated case is:

$$
\Phi_{1}\left(X_{c i} \beta_{c}\right)
$$

The contribution for a withdrawn case is:

$$
\Phi_{2}\left(-X_{c i} \beta_{c}, X_{w} \beta_{w} ;-\rho_{w c}\right)
$$

The contribution for a case decided by the elected judges in favor of the employee:

$$
\Phi_{3}\left(-X_{c i} \beta_{c},-X_{w i} \beta_{w}, X_{d i} \beta_{d} ; V\right)
$$

The contribution for a case decided by the elected judges against the employee:

$$
\Phi_{3}\left(-X_{c i} \beta_{c},-X_{w i} \beta_{w},-X_{d i} \beta_{d} ; V^{\prime}\right)
$$

The associated Stata maximization program is: 


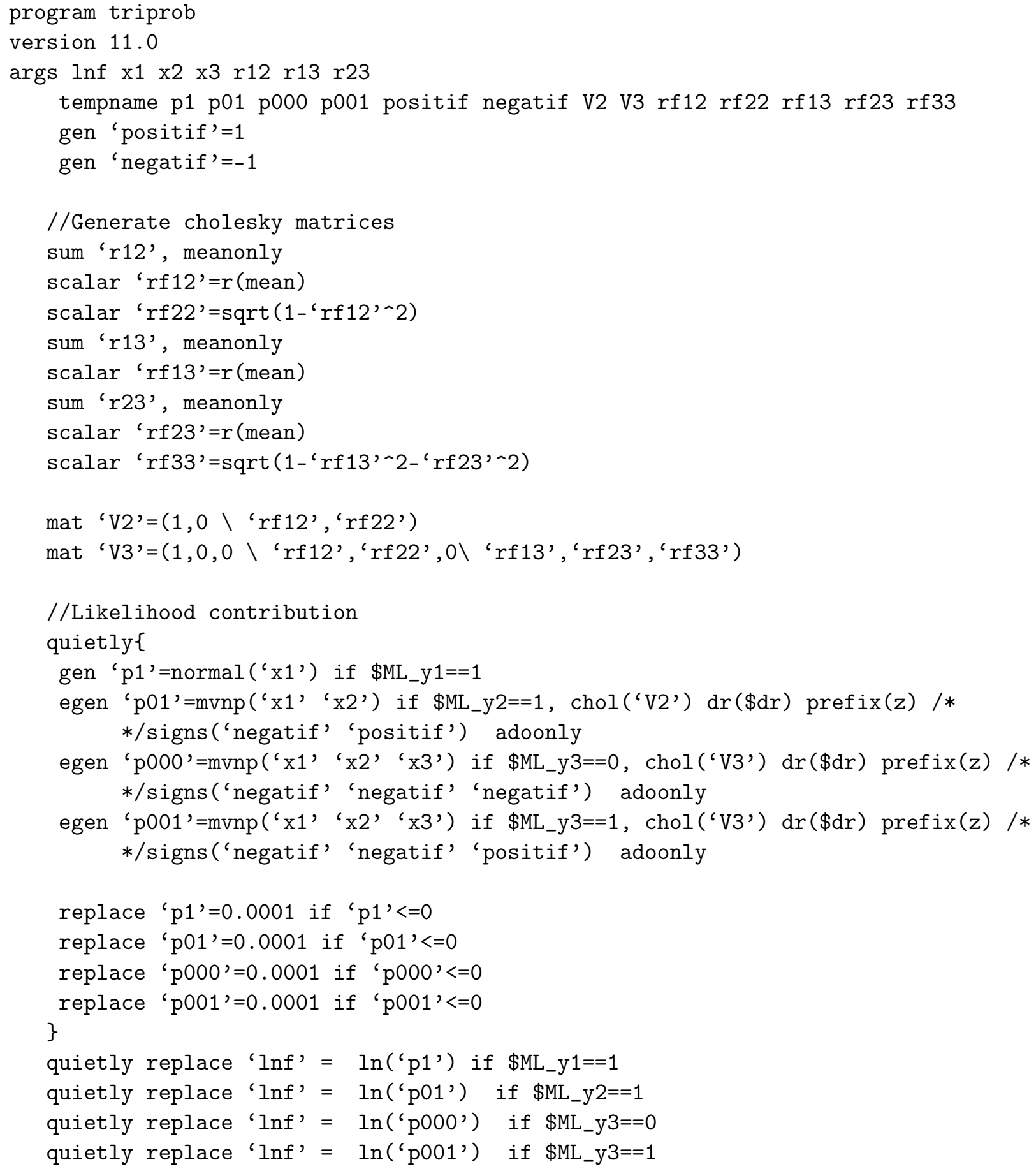

end

The maximization of the likelihood is computationally very demanding. In order to estimate the model, we randomly selected $75 \%$ of the cases and maximized the above program. Identification was insured by the fact that (i) values of the variables of the conciliation step are set at the date of the conciliation attempt, while they are set at the date of the first audition in front of the elected judges for the withdraw and the decision stages, and (ii) the withdraw stage includes the average 
duration of cases terminated the previous year while the decision does not. The convergence of the program took three weeks. The estimation was performed using propConfront. The results of the estimation are displayed in table Online-B1. 
Table Online-B1: Results of the triprobit estimation with Decision2

\begin{tabular}{|c|c|c|c|}
\hline Step & Conciliation & Withdraw & Decision2 \\
\hline propConfront & $\begin{array}{l}.0349^{*} \\
(1.72)\end{array}$ & $\begin{array}{c}.3456^{* * *} \\
(19.00)\end{array}$ & $\begin{array}{l}-.0001 \\
(-0.00)\end{array}$ \\
\hline shareLeft & $\begin{array}{l}.2428 \\
(1.46)\end{array}$ & $\begin{array}{c}.3140^{* * *} \\
(2.68)\end{array}$ & $\begin{array}{l}.0162 \\
(0.11)\end{array}$ \\
\hline avDuraffLY & $\begin{array}{c}1.21 \mathrm{e}-05 \\
(0.52)\end{array}$ & $\begin{array}{c}-.00016^{* * *} \\
(-8.31)\end{array}$ & \\
\hline unemployment & $\begin{array}{c}-.00188^{* *} \\
(-2.07)\end{array}$ & $\begin{array}{c}-.0081^{* * *} \\
(-7.89)\end{array}$ & $\begin{array}{c}-.00256^{*} \\
(-1.91)\end{array}$ \\
\hline $\operatorname{lngdppc}$ & $\begin{array}{c}.5288^{* * *} \\
(6.95)\end{array}$ & $\begin{array}{c}-.4783^{* * *} \\
(-11.17)\end{array}$ & $\begin{array}{c}-.4392^{* * * *} \\
(-7.82)\end{array}$ \\
\hline gender & $\begin{array}{c}.0701^{* * *} \\
(19.88)\end{array}$ & $\begin{array}{c}-.0364^{* * *} \\
(-11.61)\end{array}$ & $\begin{array}{c}.0539^{* * *} \\
(12.08)\end{array}$ \\
\hline def_lawyer & $\begin{array}{c}-.2737^{* * *} \\
(-50.15)\end{array}$ & $\begin{array}{c}-.1226^{* * *} \\
(-24.15)\end{array}$ & $\begin{array}{c}.0871^{* * *} \\
(12.02)\end{array}$ \\
\hline def_workerUnion & $\begin{array}{l}-.0765 \\
(-1.00)\end{array}$ & $\begin{array}{l}-.1175 \\
(-1.55)\end{array}$ & $\begin{array}{l}-.0561 \\
(-0.66)\end{array}$ \\
\hline def_employerUnion & $\begin{array}{c}.4008^{* * *} \\
(11.94)\end{array}$ & $\begin{array}{c}-.4122^{* * *} \\
(-10.06)\end{array}$ & $\begin{array}{c}-.3000 * * * \\
(-6.57)\end{array}$ \\
\hline plaint_lawyer & $\begin{array}{c}.0966^{* * *} \\
(15.79)\end{array}$ & $\begin{array}{c}-.1438^{* * *} \\
(-23.40)\end{array}$ & $\begin{array}{l}.0106 \\
(1.10)\end{array}$ \\
\hline plaint_union & $\begin{array}{c}.2637^{* * *} \\
(33.71)\end{array}$ & $\begin{array}{c}-.2167^{* * *} \\
(-26.87)\end{array}$ & $\begin{array}{l}-.0731 \\
(-5.77)\end{array}$ \\
\hline$\rho_{c w}$ & & $\begin{array}{c}-0.685^{* * *} \\
(-39.14)\end{array}$ & \\
\hline$\rho_{c d}$ & & $\begin{array}{c}-0.284^{* * *} \\
(-7.69)\end{array}$ & \\
\hline$\rho_{w}$ & & $\begin{array}{c}0.16844^{* * *} \\
\quad(3.65)\end{array}$ & \\
\hline Observations & & 905,125 & \\
\hline Log-Likelihood & & $-1,123,310.9$ & \\
\hline
\end{tabular}

First step: conciliation; second step: withdraw; third step: Elected judges' decision to accept the employee's claim.

$\rho_{c w}$ : correlation between the error terms of the conciliation step and the withdraw step.

$\rho_{c d}$ : correlation between the error terms of the conciliation step and the elected judges' decision to accept the employee's claim.

$\rho_{w d}$ : correlation between the error terms of the withdraw step and the elected judges' decision to accept the employee's claim.

Significance level: ${ }^{* * *}$ significant at $1 \%$ level; ${ }^{* *}$ significant at $5 \%$ level; * significant at $10 \%$ level. Z-statistics in parentheses. 
Table Online-B2: Results of the triprobit estimation with Referral.

\begin{tabular}{|c|c|c|c|}
\hline Step & Conciliation & Withdraw & Referral \\
\hline propConfront & $\begin{array}{l}.0196 \\
(1.06)\end{array}$ & $\begin{array}{l}.334^{* * *} \\
(19.08)\end{array}$ & $\begin{array}{l}.0273 \\
(1.49)\end{array}$ \\
\hline shareLeft & $\begin{array}{c}.744^{* * *} \\
(4.84)\end{array}$ & $\begin{array}{l}.0735 \\
(0.65)\end{array}$ & $\begin{array}{c}-.311^{* * *} \\
(-2.57)\end{array}$ \\
\hline avDuraffLY & $\begin{array}{c}.0001^{* * *} \\
(4.97)\end{array}$ & $\begin{array}{c}-.0002^{* * *} \\
(-12.57)\end{array}$ & \\
\hline unemployment & $\begin{array}{l}.0011 \\
(1.46)\end{array}$ & $\begin{array}{c}-.0062^{* * *} \\
(-6.27)\end{array}$ & $\begin{array}{l}-.0008 \\
(-0.84)\end{array}$ \\
\hline $\operatorname{lngdppc}$ & $\begin{array}{c}1.451^{* * *} \\
(21.61)\end{array}$ & $\begin{array}{c}-.726^{* * *} \\
(-17.40)\end{array}$ & $\begin{array}{c}1.893^{* * *} \\
(40.50)\end{array}$ \\
\hline gender & $\begin{array}{c}.0617^{* * *} \\
(18.17)\end{array}$ & $\begin{array}{c}-.0368^{* * *} \\
(-12.23)\end{array}$ & $\begin{array}{c}.0626^{* * *} \\
(18.99)\end{array}$ \\
\hline def_lawyer & $\begin{array}{c}-.246^{* * *} \\
(-45.69)\end{array}$ & $\begin{array}{c}-.1036^{* * *} \\
(-21.49)\end{array}$ & $\begin{array}{c}-.185^{* * *} \\
(-33.82)\end{array}$ \\
\hline def_workerUnion & $\begin{array}{l}.0154 \\
(0.21)\end{array}$ & $\begin{array}{c}-.215^{* * *} \\
(-2.80)\end{array}$ & $\begin{array}{l}-.0287 \\
(-0.37)\end{array}$ \\
\hline def_employerUnion & $\begin{array}{l}.444^{* * *} \\
(13.66)\end{array}$ & $\begin{array}{c}-.320 * * * \\
(-8.09)\end{array}$ & $\begin{array}{c}.186^{* * *} \\
(4.83)\end{array}$ \\
\hline plaint_lawyer & $\begin{array}{l}.204^{* * *} \\
(33.42)\end{array}$ & $\begin{array}{c}-.154^{* * *} \\
(-25.64)\end{array}$ & $\begin{array}{l}.116^{* * *} \\
(15.12)\end{array}$ \\
\hline plaint_union & $\begin{array}{l}.392^{* * *} \\
(50.72)\end{array}$ & $\begin{array}{c}-.233^{* * *} \\
(-29.57)\end{array}$ & $\begin{array}{l}.240^{* * *} \\
(25.41)\end{array}$ \\
\hline$\rho_{c w}$ & & & $\begin{array}{c}-.691^{* * *} \\
(-59.74)\end{array}$ \\
\hline$\rho_{c, r e f}$ & & & $\begin{array}{c}0.927^{* * *} \\
(226.09)\end{array}$ \\
\hline$\rho_{w, r e f}$ & & & $\begin{array}{c}-0.641^{* * *} \\
(-42.93)\end{array}$ \\
\hline Observations & & & $1,006,717$ \\
\hline Log-Likelihood & & & $-1,128,591$ \\
\hline
\end{tabular}

Significance level: ${ }^{* * *}$ significant at $1 \%$ level $* *$ significant at $5 \%$ level $*$ significant at $10 \%$ level.

First step: conciliation; second step: withdraw; third step: Referral to a professional judge.

$\rho_{c w}$ : correlation between the error terms of the conciliation step and the withdraw step.

$\rho_{c, r e f}$ : correlation between the error terms of the conciliation step and the decision to refer to a professional judge.

$\rho_{w, r e f}$ : correlation between the error terms of the withdrawal step and the decision to refer to a professional judge.

Significance level: *** significant at $1 \%$ level; ${ }^{* *}$ significant at $5 \%$ level; $*$ significant at $10 \%$ level. Z-statistics in parentheses. 